\title{
The final spawning ground of Tachypleus gigas (Müller, 1785) on the east Peninsular Malaysia is at risk: A call for action
}

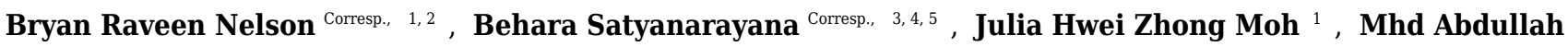 \\ Ikhwanuddin $^{6}$, Anil Chatterji ${ }^{7}$, Faizah Shaharom ${ }^{8}$ \\ 1 Universiti Malaysia Terengganu - UMT, Institute of Tropical Aquaculture (AQUATROP), 21030 Kuala Terengganu, Terengganu, Malaysia \\ 2 Universiti Malaysia Terengganu - UMT, Horseshoe Crab Research Group (HCRG), 21030 Kuala Terengganu, Terengganu, Malaysia \\ 3 Universiti Malaysia Terengganu - UMT, Mangrove Research Unit (MARU), Institute of Oceanography and Environment (INOS), 21030 Kuala Terengganu, \\ Malaysia \\ 4 Université Libre de Bruxelles - ULB, Laboratory of Systems Ecology and Resource Management, CPI 264/1, Avenue Franklin Roosevelt 50, B-1050 \\ Brussels, Belgium \\ 5 Vrije Universiteit Brussel - VUB, Laboratory of Plant Biology and Nature Management, Pleinlaan 2, B-1050 Brussels, Belgium \\ 6 Universiti Malaysia Terengganu - UMT, Institute of Tropical Aquaculture (AQUATROP), 21030 Kuala Terengganu, Malaysia \\ 7 Biological Oceanography Division, National Institute of Oceanography (NIO), 403004 Goa, Goa, India \\ 8 Universiti Malaysia Terengganu - UMT, Institute of Kenyir Research (IPK), 21030 Kuala Terengganu, Kuala Terengganu, Malaysia \\ Corresponding Authors: Bryan Raveen Nelson, Behara Satyanarayana \\ Email address: brav_11@hotmail.com, satyam2149@gmail.com
}

Tanjung Selongor and Pantai Balok (State Pahang) are the only two places known for spawning activity of the Malaysian horseshoe crab - Tachypleus gigas (Müller, 1785) on the east coast of Peninsular Malaysia. While former beach has been disturbed by several anthropogenic activities that ultimately brought an end to the spawning activity of $T$. gigas, the status of the latter remained uncertain. In the present study, the spawning behavior of $T$. gigas at Pantai Balok (Sites I-III) was observed over a period of thirty six months, in three phases, between 2009 and 2013 . Every year, the crab's nesting activity was found high duringSouthwest monsoon (May-September) followed by Northeast (November-March) and Inter monsoon (April and October) periods. In the meantime, the number of female T. gigas in 2009-2010 (Phase-1) was higher (38 crabs) than to 20102011 (Phase-2: 7 crabs) and 2012-2013 (Phase-3: 9 crabs) for which both increased overexploitation (for edible and fishmeal preparations) as well as anthropogenic disturbances in the vicinity (sand mining since 2009, land reclamation for wave breaker/parking lot constructions in 2011 and fishing jetty construction in 2013) are responsible. In this context, the physical infrastructure developments have altered the sediment close to nesting sites to be dominated by fine sand $(2.5 X \varphi)$ with moderatelywell sorted (0.6-0.7 $\sigma \varphi$ ), very-coarse skewed (-2.4 SK $\varphi$ ), and extremely leptokurtic (12.6 K $\varphi$ ) properties. Also, increased concentrations of Cadmium (from 4.2 to $13.6 \mathrm{mg} \mathrm{kg}$ ${ }^{-1}$ ) and Selenium (from 11.5 to $23.3 \mathrm{mg} \mathrm{kg}^{-1}$ ) in the sediment, and Sulphide (from 21 to $28 \mathrm{\mu g}^{-1}$ ) in the water were observed. In relation to the monsoonal changes affecting 
sheltered beach topography and sediment flux, the spawning crabs have shown a seasonal nest shifting behaviour in-between Sites I-III during 2009-2011. However, in 2012-2013, the crabs were mostly restricted to the areas (i.e. Sites I and II) with high oxygen (5.5-8.0 $\left.\mathrm{mg} \mathrm{I}^{-1}\right)$ and moisture depth $(6.2-10.2 \mathrm{~cm})$. In view of the sustained anthropogenic pressure on the coastal habitats on one hand and decreasing horseshoe crabs population on the other, it is crucial to implement both conservation and management measures for T. gigas at Pantai Balok, failing which may leadsto the loss of this final spawning ground on the east coast of P. Malaysia. 


\section{The final spawning ground of Tachypleus gigas (Müller, 1785) on the east Peninsular Malaysia is at risk: A call for action}

Bryan Raveen Nelson ${ }^{1,2, \dagger, *}$, Behara Satyanarayana ${ }^{3,4,5, \dagger, *}$, Julia Hwei Zhong Moh ${ }^{1}$, Mhd Abdullah Ikhwanuddin $^{1}$, Anil Chatterji ${ }^{6}$ and Faizah Shaharom ${ }^{7}$

${ }^{1}$ Institute of Tropical Aquaculture (AQUATROP), Universiti Malaysia Terengganu - UMT, 21030 Kuala Terengganu, Malaysia

${ }^{2}$ Horseshoe Crab Research Group (HCRG), Universiti Malaysia Terengganu - UMT, 21030 Kuala Terengganu, Malaysia

${ }^{3}$ Mangrove Research Unit (MARU), Institute of Oceanography and Environment (INOS), Universiti Malaysia Terengganu - UMT, 21030 Kuala Terengganu, Terengganu, Malaysia

${ }^{4}$ Laboratory of Systems Ecology and Resource Management, Université Libre de Bruxelles ULB, CPI 264/1, Avenue Franklin Roosevelt 50, B-1050 Brussels, Belgium

${ }^{5}$ Laboratory of Plant Biology and Nature Management, Vrije Universiteit Brussel - VUB, Pleinlaan 2, B-1050 Brussels, Belgium

${ }^{6}$ National Institute of Oceanography (NIO), Dona Paula, 403004 Goa, India

${ }^{7}$ Institute of Kenyir Research (IPK), Universiti Malaysia Terengganu - UMT, 21030 Kuala

Terengganu, Terengganu, Malaysia

†Co-first authors of this work

*Corresponding authors: brav_11@hotmail.com \& satyam2149@gmail.com

\section{ABSTRACT}

Tanjung Selongor and Pantai Balok (State Pahang) are the only two places known for spawning activity of the Malaysian horseshoe crab - Tachypleus gigas (Müller, 1785) on the east coast of Peninsular Malaysia. While former beach has been disturbed by several anthropogenic activities that ultimately brought an end to the spawning activity of $T$. gigas, the status of the latter remained uncertain. In the present study, the spawning behaviour of T. gigas at Pantai Balok (Sites I-III) was observed over a period of thirty six months, in three phases, between 2009 and 2013. Every year, the crab's nesting activity was found high during Southwest monsoon (MaySeptember) followed by Northeast (November-March) and Inter monsoon (April and October) periods. In the meantime, the number of female T. gigas in 2009-2010 (Phase-1) was higher (38 crabs) than to 2010-2011 (Phase-2: 7 crabs) and 2012-2013 (Phase-3: 9 crabs) for which both increased overexploitation (for edible and fishmeal preparations) as well as anthropogenic disturbances in the vicinity (sand mining since 2009, land reclamation for wave breaker/parking lot constructions in 2011 and fishing jetty construction in 2013) are responsible. In this context, the physical infrastructure developments have altered the sediment close to nesting sites to be dominated by fine sand $(2.5 X \varphi)$ with moderately-well sorted $(0.6-0.7 \sigma \varphi)$, very-coarse skewed (- 
40

41

42

43

44

45

$2.4 S K \varphi)$, and extremely leptokurtic $(12.6 \mathrm{~K} \varphi)$ properties. Also, increased concentrations of Cadmium (from 4.2 to $13.6 \mathrm{mg} \mathrm{kg}^{-1}$ ) and Selenium (from 11.5 to $23.3 \mathrm{mg} \mathrm{kg}^{-1}$ ) in the sediment, and Sulphide (from 21 to $28 \mu \mathrm{g} \mathrm{l}^{-1}$ ) in the water were observed. In relation to the monsoonal changes affecting sheltered beach topography and sediment flux, the spawning crabs have shown a seasonal nest shifting behaviour in-between Sites I-III during 2009-2011. However, in 20122013, the crabs were mostly restricted to the areas (i.e. Sites I and II) with high oxygen (5.5-8.0 $\left.\mathrm{mg}^{-1}\right)$ and moisture depth $(6.2-10.2 \mathrm{~cm})$. In view of the sustained anthropogenic pressure on the coastal habitats on one hand and decreasing horseshoe crabs population on the other, it is crucial to implement both conservation and management measures for T. gigas at Pantai Balok, failing which may leads to the loss of this final spawning ground on the east coast of P. Malaysia.

\section{Introduction}

The horseshoe crabs that survived by three Asian - Tachypleus gigas (Müller, 1785), Tachypleus tridentatus (Leach, 1819), Carcinoscorpius rotundicauda (Latreille, 1802), and one American Limulus polyphemus (Linnaeus, 1758), species are persisting from the Ordovician period (Rudkin \& Young, 2009). Its body with armour-like carapace, degenerated spines (adult), appendages with setae, spine-like telson, etc., shows their prehistoric appearance clearly (Walls, Berskson \& Smith, 2002; Ruppert, Fox \& Barnes, 2004; Smith, Millard \& Carmichael, 2009). Among the four species, only $C$. rotundicauda breeds in the muddy areas near mangroves while the rest spawns along the intertidal beaches of the estuarine coasts (Cartwright-Taylor et al., 2011; Nelson et al., 2015). The selective nesting behaviour of the crabs is usually facilitated by appendage setae (chemoreceptors) which can sense and detect suitable sandy/muddy substratum for their eggs incubation and hatching (Botton, 2009).

Horseshoe crabs are encountered only when they come ashore to shallow and surfprotected beaches for nesting. A male crab attached to the rear end of a female crab (using their pedipalps) is distinguished as one mating pair or amplex (Brockmann, 2003; Duffy et al., 2006; Brockmann \& Smith, 2009). In addition, satellite males - single and available close to the amplexed pairs to fertilize their eggs and, solitary females - if it is all alone, are also visible on the beaches (Mattei et al., 2010; Nelson et al., 2015). A female crab is capable of laying 200-300 
71 eggs (Chatterji \& Abidi, 1993) in varying depths $(10-20 \mathrm{~cm})$ below the sand (Botton, Tankersley 72 \& Loveland, 2010). However, its spawning activity is largely governed by season and local environmental (sediment and water) conditions (Smith, 2007; Weber \& Carter, 2009). Despite the increased scientific attention on the horseshoe crabs globally (Smith, Millard \& Carmichael, 2009; Chatterji \& Shaharom, 2009; Mattei et al., 2010; Cartwright-Taylor et al., 2011; Srijaya et al., 2014), their population is consistently decreasing over the years due to natural (e.g. coastal erosion) as well as anthropogenic disturbances (e.g. pollution, overexploitation, etc.) (Jackson et al., 2005; Ngy et al., 2007; Faurby et al., 2010; Nelson et al., 2015). In addition, the delayed maturity (between 9 and 11 years) and longer embryogenesis period (up to 42 days) (Coursey et al., 2003; Chabot \& Watson, 2010) are making these crabs vulnerable to recent changes in the coastal environments (Botton et al., 2006; Chatterji \& Shaharom, 2009; Nelson et al., 2015). In fact, L. polyphemus is recognised as 'near threatened' species, while the rest all three Asian horseshoe crabs are under "data deficient" category in the IUCN red list (IUCN, 2016).

In Malaysia, all three Asian horseshoe crabs are available. While $T$. gigas and $C$. rotundicauda are present in the coastal areas of Peninsular Malaysia, the distribution of $T$. tridentatus is restricted to East Malaysia (i.e. Sabah and Sarawak) (Chatterji et al., 2008). Although several researchers in P. Malaysia have worked on T. gigas, most of their findings are based on short-term investigations (e.g. Zaleha et al., 2010, John et al., 2011; Kamaruzzaman et al., 2011; Tan, Christianus \& Satar, 2011; John, Jalal \& Kamaruzzaman, 2013). The only longterm (2009-2011) study that examined the nesting behaviour of $T$. gigas was carried out by Nelson et al. (2015) from Tanjung Selongor. In fact, Tanjung Selongor and Pantai Balok (in State Pahang) are the only two places known for $T$. gigas spawning on the east coast of P. Malaysia. According to Nelson et al. (2015), the physical infrastructural developments such as jetty and road/bridge constructions at Tanjung Selongor have already brought an end to the spawning activity of T. gigas. In the case of Pantai Balok, Zaleha et al. (2012), Tan et al. (2012), and John et al. (2012) have observed the spawning populations and nesting behaviour of $T$. gigas, but for different months in 2009-2010 with no seasonal cross-checking. Therefore, an assessment on the seasonal impact as well as state-of-the-art information on T. gigas is necessary and still to be ascertained from Pantai Balok. 
102

103

104

105

106

107

108

109

110

111

112

113

114

115

116

117

118

119

120

121

122

123

124

125

126

127

128

129

130

131

22

The present study was aimed at investigating the relationship between the nesting activity of T. gigas and the environmental (water/sediment) conditions noticed at Pantai Balok. In specific, identification of major environmental factors predisposed by lunar and monsoonal changes that support $T$. gigas spawning formed the main forte of this study. In recent years, several anthropogenic activities such as sand mining (2009 - to present), land reclamation (2011), and construction of a fishing jetty (2013) also appeared to influence $T$. gigas population. At the end, a few recommendations were offered for possible conservation and management of T. gigas at Pantai Balok.

\section{Materials and Methods}

\subsection{Study area}

We recall that Pantai Balok, in State Pahang, is one of the two spawning grounds for T. gigas on the east coast of P. Malaysia (Lat: $3^{\circ} 56^{\prime} 16.58^{\prime}{ }^{\circ}-3^{\circ} 55^{\prime} 39.33^{\prime}$ ' N; Long: $103^{\circ} 22^{\prime} 32.74^{\prime}{ }^{\prime}-103^{\circ}$ 22'27.12', E) (Fig. 1A). River Balok and its tributaries opens here into South China Sea and provide a regular exchange of water (Fig. 1B). The climate of Pantai Balok is influenced by Northeast (NE) (November-March) and Southwest (SW) monsoons (May-September), separated by two Inter-monsoon (IM) periods (April and October). The weather - with a temperature varying between 20 and $36^{\circ} \mathrm{C}$, is generally hot and humid (WU, 2014). The annual (average) rainfall is about $1710.5 \mathrm{~mm}$ and occurs mostly during September-December. The tides with a range of 0.1-3.4 $\mathrm{m}$ are mixed in nature (NHC, 2013).

Pantai Balok is under sustained human intervention over the last few decades. In addition to the sand mining since 2009 (Fig. 1B), both land reclamation for wave breaker and parking lot constructions in 2011 (Fig. 1D), and fishing jetty construction in 2013 (Fig. 1E) have brought considerable changes to the beach topography, sediment and water characteristics (present study). Local people also catch the mating pairs of $T$. gigas for their food and processed feed preparations (to use in chick and fish farms). In order to carry out the present study, the local fishermen's association at Pantai Balok was consulted and obtained their permission.

\subsection{Sampling protocol}


132 The spawning activity of T. gigas was observed over a period of thirty six months in three phases

133 between 2009 and 2013. Phase-1 corresponds to the observations made from July 2009 to April

1342010 (for both full moon and new moon periods), while Phase-2 from June 2010 to June 2011

135 (only for full moon due to financial limitations), and Phase-3 from May 2012 to May 2013 (for

136 full moon and new moon periods). Overall, the dataset represents 15 months of observations

137 each for SW and NE monsoons and 6 months of observations for IM periods. Restricted to a

138 gentle slope in-between high and mid tide markings, the spawning activity of $T$. gigas was found

139 only in a portion of $381 \mathrm{~m}$ along the beach at Pantai Balok. The places that have shown regular

140 yield of nests were divided into three sampling sites namely, Site-I (3 56' $15.76^{\prime}$ ' N, $103^{\circ} 22^{\prime}$

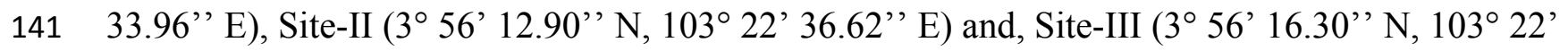

142 40.36" E) (located 105-142 m apart). Although biological and environmental parameters (as

143 outlined below) were obtained from each site for every month, the months that have shown eggs

144 and/or spawning crabs were only considered for the present analysis/interpretation (for complete

145 details, please vide the supplementary material). In order to have a better understanding on the

146 nesting activity of $T$. gigas vis-à-vis environmental conditions, the pollution indicating factors

147 such as heavy metal (i.e. Lead $(\mathrm{Pb})$, Chromium (Cr), Selenium (Se), Cadmium (Cd), Copper

$148(\mathrm{Cu})$ and Zinc $(\mathrm{Zn}))$ concentrations in the sediment; nutrient (i.e. Nitrite $\left(\mathrm{NO}_{2}{ }^{-}\right)$, Nitrate $\left(\mathrm{NO}_{3}{ }^{-}\right)$

149 and Phosphate $\left.\left(\mathrm{PO}_{4}{ }^{3-}\right)\right)$ and Sulphide $\left(\mathrm{S}^{2-}\right)$ concentrations in the water were also tested (for

150 Phases 2 and 3).

151

152 2.3. Biological observations

153 All sampling sites were visited at night/early morning during high tide for spawning crabs

154 estimation and to mark their nesting locations, whereas in daytime during low tide for nest/eggs

155 counting. The spawning (male/female) crabs of $T$. gigas were counted by sight if they are

156 available ashore and by catch (using hand) if they are submerged in water and releasing the air

157 bubbles. The places that shown air bubbles were marked with wooden stakes for nest/eggs

158 counting. The number of nests was obtained through removing the sand at the point of crab

159 imprints (using plastic hand shovel). The egg clutches from each nest were gently removed and

160 washed in situ with seawater (using $2 \mathrm{~mm}$ sieve) to count the number of eggs. After counting, all

161 eggs were placed back into the same pit and covered by the sand. However, the data on 
162 overexploitation of the crabs by local fishermen were qualitative (learnt from other villagers

163 more than to our eye witnessed accounts) and hence used only for the results interpretation.

164

165

\subsection{Hydrological observations}

166 The data on surface water quality parameters such as temperature $\left({ }^{\circ} \mathrm{C}\right)$, salinity $(\%)$, $\mathrm{pH}$ and 167 dissolved oxygen (DO) ( $\left.\mathrm{mg} \mathrm{1}^{-1}\right)$ were obtained in situ using YSI 556 multi-probe sensors (YSI 168 Inc., Yellow-Springs, OH, USA). In addition, $1000 \mathrm{ml}$ of water sample was collected from each 169 site for laboratory analyses. All samples were first filtered through microglass filter paper 170 (Whatman ${ }^{\circledR} \mathrm{GF} / \mathrm{C} 47 \mathrm{~mm}$, England) and then kept in the ice-box. While the filter paper used for 171 each sample was preserved separately in 90\% Acetone for Chl- $a$ estimation (Parsons, Maita \& 172 Lalli, 1984), the $\mathrm{pH}$ of the filtered water was adjusted to 2 by adding Hydrochloric acid ( $\mathrm{HCl})($ to 173 arrest microbial activity and stabilize organic carbon) (USEPA, 2004; Wilde et al., 2009). The 174 analyses of nutrients and sulphide were carried out in the laboratory using spectrophotometer kit 175 (HACH DREL 2400, USA) (HACH, 2004; Magarde et al., 2011).

176

177

\subsection{Sedimentological observations}

178 Both soil temperature (using thermometer, sensitivity: $\pm 0.2{ }^{\circ} \mathrm{C}$ ) and $\mathrm{pH}(\mathrm{DM}-13$ Takamura 179 Electric Works, Japan) were recorded in situ at the time of nest/egg counting. A transparent PVC 180 tube with 3" diameter and $1 \mathrm{~m}$ length (marked up to $50 \mathrm{~cm}$ ) was pushed into the sediment and, the depth above the anoxic/black sand layer was measured as moisture depth at each sampling

183

184

185

186

187

188

189

190

191 site. In addition, $\sim 500 \mathrm{~g}$ of surface sediment was collected from each site (using hand shovel) for the laboratory analyses. About $100 \mathrm{~g}$ of the sediment was oven dried for 3 days (at $45^{\circ} \mathrm{C}$ ) and then separated into different fractions (using $<63$ to $4000 \mu \mathrm{m}$ sieves) using a mechanical sieve shaker (Retsch AS 200 Basic, Germany). The logarithmic method of moments was used to estimate mean $(\varphi)$, sorting $(\sigma \varphi)$, skewness $(S K \varphi)$ and kurtosis $(K \varphi)$ values in the samples (Blott and Pye, 2001). The sediment fraction $<63 \mu \mathrm{m}$ was used for heavy metal analysis through Inductively Coupled Plasma Optical Emission Spectrometry (ICP-OES) (Varian Vista-Pro, USA) (Noriki et al., 1980). The total organic carbon (TOC) in the samples was estimated using a TOC analyser (Shimadzu, TOC-VCPH, Japan) (Schumacher, 2002; USEPA, 2004). In addition, the sediment enrichment factor (Leong, Kamaruzzaman \& Zaleha, 2003) and the geo- 
192 accumulation index (Din, 1992) were derived for understanding the impact of pollution in the 193 vicinity.

194

195

\subsection{Statistical analyses}

The statistical variations within biological and environmental parameters (at $P<0.05$ ) were tested through One-Way ANOVA (using OriginPro v.9.1 software), for which the data obtained for each (select) parameter from every month in Phases 1-3 were considered. In this context, the phasewise information was treated as (1-3) dependent groups and tested against to the samplings (I-III) sites, monsoon (SW, NE and IM) seasons, and lunar (full moon and new moon) periods as independent groups. The Principle Component Analysis (PCA) was also used to identify the percentage (\%) variation between environmental (sediment and water) parameters and T. gigas egg counts (roottransformed data) (using PRIMER v.6 software) (Clarke and Gorley, 2006). To establish the species-environment relationship, a routine called BEST - amalgamating BIO-ENV and BVSTEP procedures, in PRIMER v.6 was followed (with 999 permutations). In this context, the Spearman's rank correlation coefficients ( $\rho$ values) were considered for denoting positive and negative impact of the environmental variables on $T$. gigas nesting sites.

\section{Results}

\subsection{Spawning population and nesting}

211 Out of thirty-six months investigation, the spawning activity of $T$. gigas was found only for 212 twenty-two months, especially during SW monsoon followed by NE and IM periods (Tables 1-5) 213 (Fig. 2A). The full moon observations revealed higher egg/nest yield (102-208 nos.) than to the 214 new moon observations (82-121 nos.) (Fig. 2B), where the differences were non-significant 215 (Table 6). In total, 117 spawning crabs (males: 63 and females: 54) were recorded for the entire period of investigation. Despite the highest number of spawning crabs at Site-II, Site-III showed maximum egg/nest yield followed by Site-I (Fig. 2C). Although number of the spawning crabs was higher for 2009-2010 (Phase-1: 69 crabs), it decreased during 2010-2011 (Phase-2: 20 crabs) and 2012-2013 (Phase-3: 28 crabs) (Fig. 2D). Another important observation is that the female crabs dug more number of nests (up to 32) and released more number of eggs (3.977 nos. in 43 clutches) in Phase-3 than to Phase-1 (23 nests and 3,025 eggs in 28 clutches) or Phase-2 (9 nests, 
223 in Phase- 1 to 7 in Phase- 2 and 4 in Phase-3, along with the solitary females from 25 in Phase- 1

224 to 5 in Phase-3. At the time of less anthropogenic intervention (i.e. Phase-1), T. gigas displayed a 225 seasonal nest shifting behaviour from open coastal area (Sites II-III) in SW monsoon to sheltered 226 beach (Site-I) in NE and IM periods (Tables 1-2) (Fig. 6).

227

228

\subsection{Sediment characteristics}

229

230

231

232

233

234

235

236

237

238

239

240

241

242

243

244

245

246

247

248

249

250

251

252 253

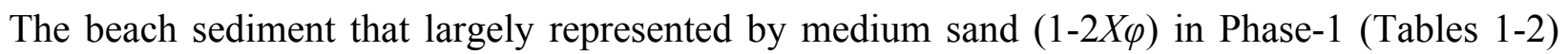
was changed into fine sand $(>2 X \varphi)$ in Phases 2 and 3 (Tables 3-5). Categorically, the sediment fraction that contained $0.250 \mathrm{~mm}$ (representing medium sand) was more in Phase-1, whereas it replaced by $0.180 \mathrm{~mm}$ (representing medium-fine sand) in Phase- 2 and $0.125 \mathrm{~mm}$ (representing fine sand) in Phase-3. For Phase-1, the sediment was represented by moderately-well sorted to poorly sorted $(0.5-1.7 \sigma \varphi)$, symmetrical to very-fine skewed $(0.0-0.7 S K \varphi)$, and very leptokurtic to extremely leptokurtic $(2.1-4.6 K \varphi)$ properties (Tables 1-2). In the case of Phase-2, except skewness (i.e. fine skewed to very-fine skewed: $0.1-3.1 S K \varphi)$, both sorting $(0.5-1.4 \sigma \varphi)$ and kurtosis $(2.5-20.5 \mathrm{~K} \varphi)$ remained as same as Phase-1 (Table 3). The well-sorted to moderately sorted $(0.4-1.0 \sigma \varphi)$, very-coarse skewed (-3.1- -1.1 SK $\varphi)$, and extremely leptokurtic $(7.8-16.8 K \varphi)$ properties have characterised the sediment collected for Phase-3 (Tables 4-5). Although not much variation in the moisture depth between Phase-1 and Phase-2 (average, 4.2-4.4 cm), it was rather increased in Phase-3 (to $6.8 \mathrm{~cm}$ ). A significant decrease in (average) silt and clay, and $\mathrm{pH}$ measurements was observed between Phase-1 and Phase-3 (Table 6). The changes in TOC between Phase-2 and Phase-3 were insignificant, except for SW vs. NE monsoon (Table 6).

In terms of the season, also both fine and medium-fine sand contents (with moderately to moderately-well sorted nature) were high for NE and IM periods whereas more gravel and silt and clay (with poor to moderately sorted nature) for SW monsoon (Tables 1-5). The three

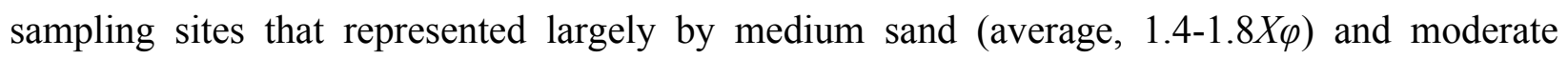
sorting $(0.8-1.0 \sigma \varphi)$ characteristics in Phases 1-2 were replaced by fine sand $(2.5 X \varphi)$ with moderately-well sorted sediment $(0.6-0.7 \sigma \varphi)$ in Phase-3. While its skewness decreased from symmetrical $(0.1 S K \varphi)$ to very-coarse skewed $(-2.4 S K \varphi)$, the kurtosis increased from very leptokurtic $(2.7 \mathrm{~K} \varphi)$ to extremely leptokurtic $(12.6 \mathrm{~K} \varphi)$ between Phase-1 and Phase-3 (Tables 15). 
Heavy metal concentrations at the three nesting sites have followed the order of $\mathrm{Cr}>\mathrm{Zn}>\mathrm{Se}>\mathrm{Pb}>\mathrm{Cu}>\mathrm{Cd}$ for Phase-2 (Tables 3-5). In Phase-3, the increased concentrations of Se

257 258

259

260

261

262

263

264

265

266

267

268

269

270

271

272

273

274

275

276

277

278

279

280

281

282

283

284 and $\mathrm{Cd}$ at Sites I-II (in the order of $\mathrm{Se}>\mathrm{Zn}>\mathrm{Cr}>\mathrm{Cd}>\mathrm{Pb}>\mathrm{Cu}$ ) and increased concentrations of $\mathrm{Zn}$, $\mathrm{Se}, \mathrm{Cd}$ at Site-III (in the order of $\mathrm{Zn}>\mathrm{Se}>\mathrm{Cr}>\mathrm{Pb}>\mathrm{Cd}>\mathrm{Cu}$ ) observed. However, in terms of metal induced enrichment at the sampling sites, only $\mathrm{Cd}$ and Se have shown their extremity (Tables 78). Also, the geo-accumulation index suggests a heavy to extreme contamination of both $\mathrm{Cd}$ and Se at all sampling sites, especially during 2011-2013 (Tables 7-8).

\subsection{Water characteristics}

Although Phase-2 and Phase-3 observations indicated a general trend of higher salinity during SW monsoon (25.3-28.0\%o), followed by IM (7.6-16.2\%o) and NE periods (9.3-10.8\%o) (Tables 3-5), Phase-1 reveals a euhaline (>30\%o) condition for all three seasons (Tables 1-2). The seasonal differences in surface water temperature, $\mathrm{pH}$ and $\mathrm{DO}$ were non-significant (Table 6). Also, the nutrients - $\mathrm{NO}_{2}^{-}, \mathrm{NO}_{3}{ }^{-}$and $\mathrm{PO}_{4}{ }^{3-}$, and Chl- $a$ (observed for Phases 2-3) showed nonsignificant differences in relation to the seasons, except by $\mathrm{NO}_{3}{ }^{-}$for $\mathrm{SW}$ vs. NE monsoon. The concentration of $\mathrm{S}^{2-}$ was however high for IM $\left(38.9 \pm 25 \mu \mathrm{g} \mathrm{l}^{-1}\right)$ (mean $\left.\pm \mathrm{SD}\right)$, followed by $\mathrm{NE}$ $\left(29.4 \pm 20 \mu \mathrm{g}^{-1}\right)$ and SW $\left(20.8 \pm 25 \mu \mathrm{g} \mathrm{l}^{-1}\right)$ in the order. Overall, the variations in water quality parameters with respect to full/new moon periods, sampling sites and seasons were insignificant (Table 6).

\subsection{Correlation between biological and environmental parameters}

The PCA drawn between biological and sediment parameters showed $49.7 \%$ variance along axis1 (eigenvalue: 6.96), and 13.2\% variance along axis-2 (eigenvalue: 1.85) (Fig. 3). The total egg count was primarily associated with Phases 1 and 3, whereas its fall in Phase-2 was evident (Fig. 3A). While Phase-1 egg yield was largely associated with medium sand, silt and clay and gravel, the Phase-3 egg yield had other parameters like mean grain size, fine sand, medium-fine sand, temperature, moisture depth, etc., and shows the impact of monsoon (Fig. 3B), lunar period (Fig. 3C) as well as the preferred sites for T. gigas nesting (Fig. 3D). The BEST analysis has indicated that mean grain size is strongly correlated with the egg laying capacity of $T$. gigas $(\rho=0.137)$. In the case of water quality, the PCA shows $46.8 \%$ variance along axis-1 (eigenvalue: 4.21 ), and 
285 18.5\% variance along axis-2 (eigenvalue: 1.67) (Fig. 4). In fact, majority of the water quality

286

287

288

289

290

291

292

293

294

295

296

297

298

299

300

301

302

303

304

305

306

307

308

309

310

311

312

313

314

315 variables were associated with Phase-3 egg counts (Fig. 4A) that occurred largely during SW monsoon (Fig. 4B), full moon periods (Fig. 4C) and at Sites I and III (Fig. 4D). The BEST analysis indicated that both (water) temperature and $\mathrm{NO}_{3}{ }^{-}$were correlated with $T$. gigas nesting activity $(\rho=0.069)$. Finally, the impact of heavy metals was seen only on Phase-3 (Fig. 5A) in relation to SW monsoon (Fig. 5B), full/new moon phases (Fig. 5C) and largely at Sites I-II (Fig. 5D) (cumulative variance along axis-1 (eigenvalue: 2.01 ) and axis-2 (eigenvalue: 1.83): 64.1\%). The BEST analysis showed a strong correlation of $\mathrm{Cr}$ and Se with the observed egg yield $(\rho=$ $0.032)$.

\section{Discussion}

\subsection{State-of-the-art on Tachypleus gigas population at Pantai Balok}

The impact of local environmental changes can easily be witnessed through declining or loss of biodiversity (Essl et al., 2015). Although Pantai Balok has been supporting the arrival of T. gigas for decades (pers. comm. with local people), the increased anthropogenic disturbances in recent years (e.g. settlements, pollution) are severely affecting the spawning crab's arrival (Tan et al., 2012; Azwarfarid et al., 2013). In fact, the present study also stands in support of this scientific concern. After discovering that T. gigas have stopped their spawning activity at Tanjung Selangor since 2011 (Nelson et al., 2015), we expected more number of crabs and higher spawning activity at Pantai Balok that located $\sim 37 \mathrm{~km}$ away from Tanjung Selangor (on the north). But the present study indicates further decline in $T$. gigas population due to sediment/water quality changes brought by the physical infrastructure developments locally (during 2011-2013).

The loss of horseshoe crabs could vary between genders. The male and female ratio of 31:38 in Phase-1 was decreased to 13:7 in Phase-2 and 19:9 in Phase-3. The sign of more males can indicate 'spawning strategies' and 'sperm competition' (i.e. satellite behaviour and tandem mating) which is known to occur in the areas of small horseshoe crab assemblages (Schaller, 2002; Brockmann \& Smith, 2009; Mattei et al., 2010; Brockmann \& Johnson, 2011; Beekey \& Mattei, 2015). On the other hand, overexploitation of the female crabs by local communities is also responsible (at least to some extent) for its reduced counts. The demand for female 
316 horseshoe crabs was reported previously from different countries like Thailand, India, America,

317 Malaysia, etc. (Christianus \& Saad, 2009; Basudev et al., 2013; Beekey \& Mattei, 2015). Yet the 318 negligible encrustation of fouling organisms on female $T$. gigas (with clear mating scars) at

319 Pantai Balok shows healthy nature of the organisms (cf. Brockmann, 2002). Also, their arrival to 320 Balok beach (despite the anthropogenic disturbances) confirms this place as a choice and still 321 supporting the environmental cues (Chabot \& Watson, 2010), beach topography (Chatterji et al., 322 2008; Jackson \& Nordstrom, 2009; Brockmann \& Johnson, 2011), and sediment/water 323 characteristics (Chatterji \& Shaharom, 2009; Smith et al., 2011; Zaleha et al., 2011; John et al., 324 2012; Nelson et al., 2015) that necessary for T. gigas spawning. Therefore, appropriate 325 conservation and management efforts would be able to retain not only this crab's population, but 326 also its final spawning ground on the east coast of P. Malaysia.

327

\subsection{Factors influenced the spawning activity of Tachypleus gigas at Pantai Balok}

At the beginning of this study (Phase-1), only sand mining was presumed to have an impact on water and sediment characteristics and bring changes to the spawning activity of T. gigas. However, this specific concern had no opportunity to compare with earlier studies/findings from Pantai Balok. But the later on developments in the form of wave breaker/parking lot (Phase-2) and fishing jetty (Phase-3) constructions provided a better understanding on the local environmental changes vis-à-vis $T$. gigas population dynamics. It was clear that the sediment close to spawning sites experienced a series of changes and finally became dominated by fine sand with moderate to well-sorting, very coarse skewed and extremely leptokurtic properties. However, the occurrence of more nests and eggs in Phase- 3 was suggesting that fine sand, along with medium sand (of moderate sorting, symmetrical and very leptokurtic properties) as reported by Zaleha et al. (2012) and Nelson et al. (2015), also supports the spawning activity of T. gigas (mean grain size as strongly correlated). In addition, the average egg laying capacity of a female in Phase-3 (>400 nos.) was five times higher than to Phase-1 (80 nos.), and exceeded the counts

342 (as max. 200-390 eggs) reported from Malaysia and India (Chatterji \& Abidi, 1993; Chatterji et al., 2004a,b; Zaleha et al., 2012). In this context, the restricted distribution of the spawning crabs to the areas of high moisture depth and well oxygenated water was found crucial. The enhanced primary productivity in the estuaries due to Nitrogen and its derivatives could attract not only 
347 which feed on a variety of prey (Carmichael et al., 2004). While the correlation observed

348 between $\mathrm{NO}_{3}{ }^{-}$and $T$. gigas nesting is likely to benefit the adult crabs forage (Carmichael et al., 349 2004; Haramis et al., 2007), the temperature could bring a physical stress to the eggs (e.g. 350 desiccation) (Ehlinger \& Tankersley, 2004; Botton et al., 2006).

351

352

353

354

355

356

357

358

359

360

361

362

363

364

365

366

367

368

369

370

371

372

373

374

375

376

377

Although earlier researchers from Malaysia claimed year-round spawning activity of $T$. gigas (Zaleha et al., 2012; John et al., 2012; John, Jalal \& Kamaruzzaman, 2013), the present study confirms it only between March and November, but covering all three seasons. However, there seemed to be a considerable influence of salinity on the egg laying capacity of female $T$. gigas. For instance, in Phases 2 and 3 when there was a general trend of high salinity during SW monsoon, the average number of eggs laid by a female was only 148-372 nos. (despite the fact that SW favoured more spawning crabs, more nests and eggs). But with not many eye witness accounts on female crabs $(n=0-1)$ and if the total number of eggs is taken into account for other two seasons, there were as high as 556-967 nos. for NE monsoon and 32-360 nos. for IM period. While the maximum egg yield in SW and IM periods is rather similar, it was remarkably high for NE monsoon. This is however in contrast to the findings of Nelson et al. (2015) who reported no T. gigas spawning for NE monsoon at Tanjung Selangor. Perhaps the differences in geographic location, beach topography, low/high impact of the seasonal water current (especially during NE monsoon) on spawning sites, etc., are attributable for the differences encountered between present study and Nelson et al. (2015). In the case of Phase-1, the euhaline conditions should have impacted the normal spawning activity of T. gigas (average no. of eggs laid by a female: 58 in SW, 50 in NE and 150 in IM). The poor sediment sorting - which in turn represents a weak water circulation/tidal mixing (Watanabe et al., 2014), very-fine skewed and extremely leptokurtic properties are all stand in support for the observed euhaline situation. The narrowed river mouth in 2009-2010 was believed to be the main reason for this condition.

Horseshoe crabs avoid the areas with vigorous tides and prefer relatively calm places for its spawning (FitzGerald et al., 2008; Smith et al., 2011; Tan et al., 2012). At Pantai Balok, the spawning crabs preferred Site-I during NE and IM periods, and Sites II and III during SW monsoon. In South China Sea, the strong water current (with strong wind and waves) prevails during NE and IM (Camerlengo \& Demmler, 1997; Akhir, Sinha \& Hussain, 2011), and 
378 therefore the spawning crabs have chosen the interior location (i.e. Site-I) for their nesting. In

379 fact, the spawning behaviour of the horseshoe crabs in relation to seasonal water current was 380 explained by different authors from India (Chatterji, Parulekar \& Qasim, 1996), Malaysia

381 (Nelson et al., 2015), America (Berkson and Shuster, 1999), etc. Nevertheless, the horseshoe 382 crabs are able to detect metal contamination and usually stay away from such locations (Itow, 383 1997a,b). However, the extremity of $\mathrm{Cd}$ and Se (though found strongly correlated) in the 384 sediment not yet completely challenged the spawning crab's arrival to Pantai Balok and still 385 giving a hope for its resurgence if the ongoing anthropogenic disturbances are regulated through 386 appropriate conservation and management efforts.

387

\subsection{Conservation and management measures for Tachypleus gigas at Pantai Balok}

Due to poor understanding on the horseshoe crab population dynamics and breeding biology, several of its known as well as unknown spawning grounds are on the verge of extinction (Chiu \& Morton, 2003; Ehlinger \& Tankersley, 2007; Moore and Perrin, 2007; Cartwright-Taylor, Lee \& Hsu, 2009). On the east coast of P. Malaysia, the current situation of halted spawning activity by T.gigas at Tanjung Selangor might also occur at Pantai Balok if no regulations on the beach constructions are imposed. For instance, the concerned governmental and/or non-governmental authorities should check for the Environmental Impact Assessment before starting any construction work(s) at Pantai Balok. Also, appropriate care should be taken to prevent overexploitation of the crabs (especially females) for edible and fishmeal preparations. The awareness on horseshoe crabs significance and possible health hazards, if they were caught and consumed from polluted areas, must be created among the local people. Also, the standardized sampling protocols would be able to develop a strong database for future scientific comparisons and effective long-term monitoring (cf. Botton, 2001; Sekiguchi \& Shuster, 2009; Shuster \& Sekiguchi, 2009). Although several law and enforcement rules are available for protection of the forest reserves, biodiversity, etc., in Malaysia, the horseshoe crabs still to acquire a gazetted status. In fact, the additional protection offered to majority animals under the Fisheries Act 1985 (Act 317) and the Wildlife Conservation Act 2010 (Act 716) in Malaysia did not include the horseshoe crabs so far. Therefore, it is mandatory to have a nation-wide priority on the conservation and management of these crabs. Perhaps the community involved management 
409 vicinity. For a quick start, the signboards indicating 'prohibited horseshoe crab fishing' at Pantai

410 Balok are necessary. In addition, the knowledge sharing programs like 'touch and feel', 411 'measure, tag and release', etc., which were conducted in the places like Taiwan (Chen, Yeh \& 412 Lin, 2004; Hsieh \& Chen, 2009) could be adopted and incorporated into the local conservation 413 module. If the above propositions are followed then it is going to benefit not only T. gigas, but 414 also other two Asian horseshoe crabs (T. tridentatus and C. rotundicauda) existing in Malaysia.

415

\section{5. Conclusions}

417 Present study, with a wide array of biological and environmental observations, evaluated the 418 major environmental factors that influencing T. gigas nesting at Pantai Balok. After discovering 419 the severity of anthropogenic disturbances that finally stopped the spawning activity of T. gigas 420 at Tanjung Selangor, the present paper intends to protect these crabs at Pantai Balok - the last 421 spawning ground for them on the east coast of P. Malaysia. Both medium and fine sand 422 compositions are found suitable for T. gigas spawning, provided that moderate to well-sorting, 423 symmetrical to very-coarse skewed and very leptokurtic to extremely leptokurtic conditions 424 exist. Although SW monsoon received more number of crabs, the average egg yield from a 425 female was found higher for NE followed by SW and IM, respectively. The differences in 426 male/female ratio at the spawning sites were largely due to overexploitation of the female crabs 427 for edible and fishmeal preparations. The spawning crabs have also shown a seasonal nest 428 shifting behaviour by choosing Site-I (interior estuary) during NE and IM periods (to avoid 429 strong water current), and Sites II and III for SW monsoon (mild water current). In light of the 430 crabs' choice to come and spawn at Pantai Balok (despite the increased anthropogenic 431 disturbances and pollution in recent years), it is crucial to implement all possible conservation 432 and management measures. Importantly, the horseshoe crabs should be placed under both 433 Fisheries and Wildlife Conservation Acts to bring a nation-wide attention as well as priority in 434 Malaysia.

435

436 Acknowledgements

437 The present study was administratively supported by AKUATROP, INOS and the School of 438 Marine Science and Environment (PPSMS) at the UMT. Authors wish to thank Mohammad 
439 Mokhtari and the other two unknown referees for their objective criticism and valuable 440 suggestions.

441

442 
443

444

445

446

447

448

449

450

451

452

453

454

455

456

457

458

459

460

461

462

463

464

465

466

467

468

469

470

471

\section{References}

Akhir MF, Sinha PC, Hussain ML. 2011. Seasonal variation of South China Sea physical characteristics off the east coast of Peninsular Malaysia from 2002-2010 datasets. International Journal of Environmental Science 2(2): 569-575.

Azwarfarid M, Faridah M, Izzatul-Huda AG, Fawwaz Afham MS, Asyraf AA, Amirrudin BA, Ismail N. 2013. A Preliminary Study on Asian Horseshoe Crab, Tachypleus gigas (Müller, 1785) Nesting Activity in Balok and Cherating, Pahang, Malaysia. Proceedings of the $2^{\text {nd }}$ International Conference on Alfred Russel Wallace-His Predecessors and Successors, Kuching, Sarawak, Malaysia (7-8 Nov 2013).

Basudev T, Sivakumar K, Sajan J, Satyaranjan B, Choudhury BC. 2013. Assessment of the population status and threats to the horseshoe crabs along the northern east coast of India. In: Venkataraman K, Sivaperuman C, Raghunathan C, eds. Ecology and Conservation of Tropical Marine Faunal Communities. Springer Berlin Heidelber, 137-146.

Beekey MA, Mattei JH. 2015. The mismanagement of Limulus polyphemus in Long Island Sound: What are the characteristics of a population in decline? In: Carmichael R, Botton ML, Cheung SG, eds. Changing Global Perspectives on Biology, Conservation, and Management of Horseshoe Crabs. Springer New York, 1-25.

Berkson J, Shuster Jr CN. 1999. The horseshoe crab: the battle for a true multiple-use resource. Fisheries 24(11): 6-10.

Blott SJ, Pye K. 2001. Gradistat: A grain size distribution and statistics package for the analysis of unconsolidated sediments. Earth Surface Processes and Landforms 26: 1237-1248.

Botton ML. 2009. The ecological importance of horseshoe crabs in estuarine and coastal communities: A review and speculative summary. In: Tanacredi JT, Botton ML, Smith DR, eds. Biology and Conservation of Horseshoe Crabs. Springer New York, 45-63.

Botton ML. 2001. The conservation of horseshoe crabs: What can we learn from the Japanese experience? In: Tanacredi JT, ed. Limulus in the Limelight. Kluwer Academic Publishers New York, 41-51.

Botton ML, Tankersley RA, Loveland RE. 2010. Developmental ecology of the American horseshoe crab Limulus Polyphemus. Current Zoology 56: 550-562. 
472 Botton ML, Pogorzelska M, Smoral L, Shehata A, Hamilton M.G. 2006. Thermal biology of 473 horseshoe crab embryos and larvae: A role for heat shock proteins. Journal Experimental

474

475

476

477

478

479

480

481

482

483

484

485

486

487

488

489

490

491

492

493

494

495

496

497

498

499

500

501

502 Marine Biology and Ecology 336: 65-73.

Brockmann HJ. 2003. Male competition and satellite behaviour. In: Shuster Jr CN, Barlow RB, Brockmann HJ, eds. The American Horseshoe Crab. Harvard University Press Cambridge, 50-82.

Brockmann HJ. 2002. An experimental approach to altering mating tactics in male horseshoe crabs (Limulus polyphemus). Behavioural Ecology 13(2): 232-238.

Brockmann HJ, Johnson SL. 2011. A long-term study of spawning activity in a Florida Gulf Coast population of horseshoe crabs (Limulus polyphemus). Estuaries and Coasts 34: 10491067.

Brockmann HJ, Smith MD. 2009. Reproductive competition and sexual selection in horseshoe crabs. In: Tanacredi JT, Botton ML, Smith DR, eds. Biology and Conservation of Horseshoe Crabs. Springer New York, 199-221.

Camerlengo A, Demmler MI. 1997. Wind-driven circulation of Peninsular Malaysia's eastern continental shelf. Scientia Marina 61(2): 203-211.

Carmichael RH, Rutecki D, Annett B, Gaines E, Valiela I. 2004. Position of horseshoe crabs in estuarine food webs: $\mathrm{N}$ and $\mathrm{C}$ stable isotopic study of foraging ranges and diet composition. Journal of Experimental Marine Biology and Ecology 299(2): 231-253.

Cartwright-Taylor L, Bing YV, Chi HC, Tee LS. 2011. Distribution and abundance of horseshoe crabs Tachypleus gigas and Carcinoscorpius rotundicauda around the main island of Singapore. Aquatic Biology 13: 127-136.

Cartwright-Taylor L, Lee J, Hsu CC. 2009. Population structure and breeding pattern of the mangrove horseshoe crab Carcinoscorpius rotundicauda in Singapore. Aquatic Biology 8: 61-69.

Chabot CC, Watson WH. 2010. Circatidal rhythms of locomotion in the American horseshoe crab Limulus polyphemus: Underlying mechanisms and cues that influence them. Current Zoology 56: 499-517.

Chatterji A, Shaharom F. 2009. Unusual spawning behaviour of the horseshoe crab (Tachypleus gigas, Müller) after the Tsunami along Orissa coast, India. Pertanika Journal of Science and Technology 17: 263-268. 
503 Chatterji A, Abidi SAH. 1993. The Indian horseshoe crab - A living fossil. Journal of Indian 504 Ocean Studies 1: 43-48.

505 Chatterji A, Kotnala S, Mathew R. 2004a. Effects of salinity on larval growth of horseshoe crabs, 506 Tachypleus gigas. Current Science 87: 248-250.

507 Chatterji A, Alam H, Joshi BK, Bhonde RR. 2004b. Regeneration of gill lamellae of the Indian 508 horseshoe crab, Tachypleus gigas (Müller). Current Science 87: 1511-1512.

509 Chatterji A, Zaleha K, Shahuddin H, Shaharom F. 2008. Abundance of three species of the 510 horseshoe crab along the coast of Malaysia. Journal of the Bombay Natural History Society 511 105: 209-211.

512 Chatterji A, Parulekar AH, Qasim SZ. 1996. Nesting behavior of the Indian horseshoe crab, Tachypleus gigas (Muller) (Xiphosura). In: Qasim SZ, Roonwal GS, eds. India's Exclusive Economic Zone. Omega Scientific Publishers India, 142-155.

Chen CP, Yeh HY, Lin PF. 2004. Conservation of the horseshoe crab at Kinmen, Taiwan: strategies and practices. Biodiversity \& Conservation 13: 1889-1904.

Chiu HMC, Morton B. 2003. The sediments and hydrographic characteristics of three horseshoe crab nursery beaches in Hong Kong. Journal of Ocean University of Qingdao 2: 35-43.

Christianus A, Saad CR. 2009. Traditional uses of horseshoe crabs in Malaysia and Thailand. In: Tanacredi JT, Botton ML, Smith DR, eds. Biology and conservation of horseshoe crabs. Springer New York, 616-617.

Clarke KR, Gorley RN. 2006. PRIMER v6: User Manual/Tutorial. PRIMER-E, Plymouth, UK.

Coursey Y, Ahmad N, McGee BM, Steimel N, Kimble M. 2003. Amoebocyte production begins at stage 18 during embryogenesis in Limulus polyphemus, the American horseshoe crab. Biological Bulletin 204: 21-27.

Din Z. 1992. Use of aluminum to normalize heavy-metal data from estuarine and coastal shelf sediments of Straits of Melaka. Marine Pollution Bulletin 24: 484-491.

Duffy EE, Penn DJ, Botton ML, Brockmann HJ, Loveland RE. 2006. Eye and clasper damage influence male mating tactics in the horseshoe crab Limulus polyphemus. Journal of Ethology 24: 67-74.

Ehlinger GS, Tankersley RA. 2007. Reproductive ecology of the American horseshoe crab Limulus polyphemus in the Indian River Lagoon: An overview. Florida Scientist 70: 449463. 
534 Ehlinger GS, Tankersley RA. 2004. Survival and development of horseshoe crab Limulus 535 polyphemus embryos and larvae in hypersaline conditions. Biological Bulletin 206: 87-94.

536 Essl F, Dullinger S, Rabitsch W, Hulme PE, Pys`ek P, Wilson JR, Richardson DM. 2015. 537 Delayed biodiversity change: no time to waste. Trends in Ecology and Evolution 20: 1-4.

538 Faurby S, King TL, Obst M, Hallerman EM, Pertoldi C, Funch P. 2010. Population dynamics of 539 American horseshoe crabs historic climatic events and recent anthropogenic pressures. $540 \quad$ Molecular Ecology 19: 2088-3100.

541 FitzGerald DM, Fenster MS, Argow BA, Buynevich IV. 2008. Coastal impacts due to sea-level 542 rise. Annual Review of Earth and Planetary Sciences 36: 601-647.

543 HACH. 2004. HACH DR/2400 Spectrophotometer procedure manual (Document 59400-22). 544 Hach Company, USA.

545 Haramis GM, Link WA, Osenton PC, Carter DB, Weber RG, Clark NA, Teece MA, Mizrahi DS. 546 2007. Stable isotope and pen feeding trial studies confirm the value of horseshoe crab Limulus polyphemus eggs to spring migrant shorebirds in Delaware Bay. Journal of Avian

Itow T. 1997a. The pollution of coastal waters and malformations of horseshoe crab embryos. Bulletin of the Education Faculty, Shizuoka University. Natural science series 48: 15-33.

Itow T. 1997b. Changes in segment differentiation by trichostatin A in horseshoe crab embryos. Animal Biology 6: 3-11.

IUCN (International Union for the Conservation of Nature) 2016. Tachypleus gigas - The IUCN Red List of Threatened Species (www.iucnredlist.org) (accessed 10 January 2016). horseshoe crabs (Limulus polyphemus) on developed shorelines in Delaware Bay, United crabs. Springer New York, 399-416. 
563 Jackson NL, Nordstrom KF, Smith DR. 2005. Influence of waves and horseshoe crab spawning 564 on beach morphology and sediment grain-size characteristics on a sandy estuarine beach. 565 Sedimentology 52: 1097-1108.

566 John BA, Jalal KCA, Kamaruzzaman BY. 2013. Macrobenthic diversity in horseshoe crab 567 nesting ground-Balok station, Pahang, Malaysia. Oriental Journal of Chemistry 29: 1311568 1318.

569 John BA, Sihin S, Kamaruzzaman BY, Jalal KCA. 2012. Sediment profiling of the nesting grounds of horseshoe crabs at East Peninsular Malaysia. International Journal of Biology 4: 159-165.

572

John BA, Kamaruzzaman BY, Jalal KCA, Zaleha K. 2011. Hydrology of the horseshoe crab nesting grounds at Pahang Coast, Malaysia. Oriental Journal of Chemistry 27: 1475-1483.

Kamaruzzaman BY, John BA, Megat MHA, Zaleha K. 2011. Bioaccumulation of heavy metals in horseshoe crabs (Tachypleus gigas) from Pekan, Pahang, Malaysia. Research Journal of Environmental Toxicology 5: 222-228.

Leong HF, Kamaruzzaman BY, Zaleha K. 2003. Interpretation of Anthropogenic Input of Metals in Mangrove Sediments Using Aluminium as a Reference Element. Proceedings of the KUSTEM $2^{\text {nd }}$ Annual Seminar on Sustainability and Management 2003, Malaysia, 82-85.

Magarde V, Iqbal SA, Iqbal N, Zaafarany I. 2011. Limological studies of upper lake of Bhopal (India). Oriental Journal of Chemistry 27: 703-711.

Mattei JH, Beekey MA, Rudman A, Woronik A. 2010. Reproductive behaviour in horseshoe crabs: Does density matter? Current Zoology 56: 634-642.

Moore S, Perrin S. 2007. Seasonal movement and resource-use patterns of resident horseshoe crab (Limulus polyphemus) populations in a Maine, USA estuary. Estuaries and Coasts 30: 1016-1026.

Nelson BR, Satyanarayana B, Moh JHZ, Shaharom F, Sukumaran M, Chatterji A. 2015. Episodic human activities and seasonal impacts on the Tachypleus gigas (Müller, 1795) population at Tanjung Selangor in Peninsular Malaysia, Estuaries, Coasts and Shelf Science 164: 313-323.

Ngy L, Yu CF, Takatani T, Arakawa O. 2007. Toxicity assessment for the horseshoe crab Carcinoscorpius rotundicauda collected from Cambodia. Toxicon 49: 843-847. 
593 NHC (National Hydrographic Centre of Malaysia) 2013. Malaysia Tide Tables 1 \& 2, Royal 594 Malaysian Navy, Ministry of Defence, Kuala Lumpur, 46-51.

595 Noriki S, Nakanishi K, Fukawa T, Uematsu M, Uchida T, Tsunogai S. 1980. Use of a sealed 596 Teflon vessel for the decomposition followed by the determination of chemical constituents 597 of various marine samples. Bulletin of the Faculty of Fisheries, Hokkaido University 31: $598 \quad 354-361$.

599 Parsons TR, Maita Y, Lalli CM. 1984. A Manual of Chemical and Biological Methods for 600 Seawater Analysis. Pergamon Press Oxford, 22-173.

601 Rudkin DM, Young GA. 2009. An ancient ancestry revealed. In: Tanacredi JT, Botton ML, 602 Smith DR, eds. Biology and Conservation of Horseshoe Crabs. Springer New York, 25-26.

603 Ruppert EE, Fox RS, Barnes RB. 2004. Invertebrate zoology, a functional evolutionary 604 approach. Brooks Cole Thompson California, 10-25.

605 Schaller SY. 2002. Survey of Maine horseshoe crabs (Limulus polyphemus) spawning 606 populations, 2001. Boothbay Harbor, Maine Department of Marine Resources, 1-34.

607 Schumacher BA. 2002. Methods for the determination of Total Organic Carbon (TOC) in soils 608 and sediments (NCEA-C-1282). United States Environmental Protection Agency (USEPA), 609 National Exposure Research Laboratory, North Carolina, 1-23.

610 Sekiguchi K, Shuster Jr CN. 2009. Limits on the global distribution of horseshoe crabs 611 (Limulicae): Lessons Learned from two lifetimes of observations: Asia and America. In: 612 Tanacredi JT, Botton ML, Smith DR, eds. Biology and Conservation of Horseshoe Crabs. 613 Springer New York, 5-24.

614 Shuster Jr CN, Sekiguchi K. 2009. Basic habitat requirements of the extant species of horseshoe 615 crabs (Limulacea). In: Tanacredi JT, Botton ML, Smith DR, eds. Biology and Conservation 616 of Horseshoe Crabs. Springer New York, 115-129.

617 Smith DR. 2007. Effect of horseshoe crab spawning density on nest disturbance and exhumation 618 of eggs: A simulation study. Estuaries and Coasts 30: 287-295.

619 Smith DR, Jackson NL, Nordstrom KF, Weber RG. 2011. Beach characteristics mitigate effects 620 of onshore wind on horseshoe crab spawning: implications for matching with shorebird 621 migration in Delaware Bay. Animal Conservation 14: 575-584.

622 Smith DR, Millard MJ, Carmichael RH. 2009. Comparative status and assessment of Limulus 623 polyphemus with emphasis on the New England and Delaware Bay populations. In: 
624

625

626

627

628

629

630

631

632

633

634

635

636

637

638

639

640

641

642

643

644

645

646

647

648

649

650

651

652

Tanacredi JT, Botton ML, Smith DR, eds. Biology and Conservation of Horseshoe Crabs. Springer New York, 361-386.

Srijaya TC, Pradeep PJ, Hassan A, Chatterji A, Shaharom F, Jeffs A. 2014. Colour preference and light sensitivity in trilobite larvae of mangrove horseshoe crab, Carcinoscorpius rotundicauda (Latreille, 1802). Indian Journal of Experimental Biology 52: 281-290.

Tan AN, Christianus A, Shakibazadeh S, Hajeb P. 2012. Horseshoe crab, Tachypleus gigas (Müller, 1785) spawning population at Balok beach, Kuantan, Pahang, Malaysia. Pakistan Journal of Biological Sciences 15: 610-620.

Tan AN, Christianus A, Satar MK. 2011. Epibiont infestation on horseshoe crab Tachypleus gigas (Muller) at Pantai Balok in Peninsular Malaysia. Our Nature 9: 9-15.

USEPA (United States Environmental Protection Agency) 2004. Method 9060A, Total organic carbon (Rev. 1, November 2004), 1-5.

Walls EA, Berskson J, Smith SA. 2002. The horseshoe crab, Limulus polyphemus: 200 million years of existence, 100 years of study. Reviews in Fisheries Science 10: 39-73.

Watanabe K, Kasai A, Antonio ES, Suzuki K, Ueno M, Yamashita YY. 2014. Influence of saltwedge intrusion on ecological processes at lower trophic levels in the Yura Estuary, Japan. Estuaries, Coasts and Shelf Science 139: 67-77.

WU (Weather Underground), 2014. Weather History for Kuantan Malaysia (2009-2013), Certified by National Oceanic and Atmospheric Administration (NOAA) (http://www.wunderground.com/history.html) (accessed 23 March 2014).

Weber RG, Carter DB. 2009. Distribution and development of Limulus egg clusters on intertidal beaches in Delaware Bay. In: Tanacredi JT, Botton ML, Smith DR, eds. Biology and Conservation of Horseshoe Crabs. Springer New York, 249-266.

Wilde FD, Radtke DB, Gibs J, Iwatsubo RT. 2009. Processing of water samples: Preservation, U.S. Geological Survey Techniques of Water-Resources Investigations 9 (http://pubs.water.usgs.gov/twri9A5/).

Zaleha K, John BA, Erni-Atika H, Kamaruzzaman BY, Jalal KCA. 2012. Spawning and nesting behaviour of Tachypleus gigas along the East Coast of Peninsular Malaysia. International Journal of Biology 4: 102-111. 
653 Zaleha K, Hazwani I, Siti Hamidah H, Kamaruzzaman BY, Jalal KCA. 2011. Effect of salinity 654 on the egg hatching and early larvae of horseshoe crab Tachypleus gigas (Müller, 1785) in 655 laboratory culture. Journal of Applied Sciences 11: 2620-2626.

656 Zaleha K, Kamaruzzaman BY, John BA, Ong MC. 2010. Cd, Cu and Pb concentration levels in 657 horseshoe crab nesting grounds of Pahang Coast, Malaysia. Journal of Biological Sciences 658 10: 790-794.

659 


\section{Table $\mathbf{1}$ (on next page)}

Ecobiological observations from the nesting sites of $T$ achypleusgigas at Pantai Balok during Phase-1 full moon

Table 1: Ecobiological observations from the three (I-III) nesting sites of $T$ achypleus gigas at Pantai Balok during Phase-1 (2009-2010) full moon surveys ( "-" no sample observed at the time of investigation) 


\begin{tabular}{|c|c|c|c|c|c|c|c|c|c|c|c|c|c|c|c|c|c|c|}
\hline & \multicolumn{12}{|c|}{2009} & \multicolumn{6}{|c|}{2010} \\
\hline & \multicolumn{3}{|c|}{ July } & \multicolumn{3}{|c|}{ August } & \multicolumn{3}{|c|}{ October } & \multicolumn{3}{|c|}{ November } & \multicolumn{3}{|c|}{ March } & \multicolumn{3}{|c|}{ April } \\
\hline & $\mathrm{I}$ & II & III & I & II & III & I & II & III & I & II & III & I & II & III & I & II & III \\
\hline \multicolumn{19}{|l|}{ (A) Biology } \\
\hline Nest (nos.) & - & - & 3 & - & 3 & - & 2 & - & - & 1 & - & - & 2 & - & - & 4 & - & - \\
\hline Egg (nos.) & - & - & 502 & - & 318 & - & 340 & - & - & 114 & - & - & 237 & - & - & 455 & - & - \\
\hline Clutches (nos.) & - & - & 4 & - & 3 & - & 2 & - & - & 1 & - & - & 3 & - & - & 5 & - & - \\
\hline Male (nos.) & 1 & 4 & - & - & 1 & 2 & 1 & 2 & - & 2 & - & - & 1 & 1 & - & 1 & 2 & - \\
\hline Female (nos.) & - & 2 & 4 & 2 & 2 & 4 & 4 & - & - & 2 & 1 & - & 2 & - & - & - & - & 3 \\
\hline \multicolumn{19}{|l|}{ (B) Sediment } \\
\hline Mean $(X \varphi)$ & 2.1 & 1.4 & 1.1 & 1.8 & 1.1 & 1.5 & 1.1 & 2.4 & 1.7 & 1.2 & 2.5 & 2.0 & 1.2 & 2.1 & 2.4 & 1.0 & 2.1 & 2.1 \\
\hline Sorting $(\sigma \varphi)$ & 1.0 & 0.9 & 1.1 & 1.0 & 1.0 & 1.2 & 0.9 & 0.5 & 1.4 & 0.8 & 0.7 & 1.7 & 1.0 & 0.9 & 0.9 & 1.0 & 1.0 & 1.1 \\
\hline Skewness $(S K \varphi)$ & 0.5 & 0.5 & 0.1 & 0.2 & 0.0 & 0.0 & 0.0 & 0.1 & 0.3 & 0.0 & 0.2 & 0.6 & 0.0 & 0.1 & 0.7 & 0.0 & 0.1 & 0.4 \\
\hline Kurtosis $(K \varphi)$ & 3.3 & 2.5 & 2.5 & 3.0 & 3.9 & 2.3 & 2.5 & 4.6 & 2.4 & 2.1 & 4.4 & 2.2 & 2.6 & 3.9 & 2.7 & 2.7 & 3.7 & 3.1 \\
\hline Gravel (\%) & 1.3 & 0.8 & 2.4 & 2.6 & 2.8 & 1.8 & 2.8 & 0.0 & 0.5 & 2.2 & 0.1 & 0.4 & 2.4 & 0.4 & 1.9 & 2.1 & 0.4 & 2.3 \\
\hline Sand $(\%)$ & 93.6 & 97.1 & 94.7 & 92.8 & 94.6 & 95.1 & 93.7 & 99.5 & 95.2 & 94.6 & 99.7 & 94.5 & 94.6 & 98.4 & 94.0 & 94.7 & 97.5 & 94.1 \\
\hline Silt \& Clay (\%) & 5.1 & 2.1 & 2.9 & 4.7 & 2.6 & 3.1 & 3.5 & 0.5 & 4.2 & 3.3 & 0.1 & 5.1 & 3.0 & 1.1 & 4.2 & 3.2 & 2.2 & 3.6 \\
\hline $0.125 \mathrm{~mm}(\%)$ & 4.7 & 2.2 & 1.7 & 3.2 & 1.4 & 2.4 & 1.9 & 6.0 & 4.1 & 1.9 & 5.3 & 4.3 & 1.9 & 3.2 & 3.2 & 1.7 & 3.6 & 2.7 \\
\hline $0.180 \mathrm{~mm}(\%)$ & 16.1 & 9.8 & 11.4 & 14.6 & 10.6 & 11.3 & 12.3 & 15.6 & 15.6 & 11.6 & 16.0 & 16.4 & 12.4 & 14.9 & 14.6 & 11.4 & 13.4 & 13.7 \\
\hline $0.250 \mathrm{~mm}(\%)$ & 22.3 & 20.2 & 19.5 & 21.7 & 19.0 & 20.1 & 19.5 & 20.7 & 25.8 & 19.6 & 22.5 & 27.2 & 19.7 & 24.5 & 22.7 & 19.5 & 22.7 & 20.3 \\
\hline Moisture depth (cm) & 3.2 & 5.7 & 4.8 & 4.1 & 4.6 & 4.3 & 3.5 & 2.8 & 2.4 & 2.7 & 1.9 & 2.2 & 5.1 & 5.6 & 5.9 & 6.7 & 6.3 & 6.8 \\
\hline Temperature $\left({ }^{\circ} \mathrm{C}\right)$ & 32.2 & 31.2 & 32.7 & 30.8 & 31.2 & 31.5 & 30.1 & 29.9 & 29.9 & 28.7 & 29.1 & 28.8 & 30.2 & 30.8 & 30.6 & 32.5 & 32.0 & 32.5 \\
\hline $\mathrm{pH}$ & 6.1 & 6.1 & 5.9 & 6.2 & 6.5 & 6.5 & 6.5 & 6.6 & 6.6 & 6.3 & 6.1 & 6.4 & 5.8 & 5.9 & 5.8 & 5.8 & 5.2 & 5.5 \\
\hline \multicolumn{19}{|l|}{ (C) Water } \\
\hline Temperature $\left({ }^{\circ} \mathrm{C}\right)$ & 29.4 & 29.7 & 29.5 & 30.0 & 29.6 & 29.5 & 32.9 & 33.2 & 33.4 & 29.3 & 29.4 & 29.5 & 29.5 & 29.7 & 30.1 & 31.2 & 30.8 & 30.5 \\
\hline $\mathrm{pH}$ & 7.8 & 7.5 & 7.5 & 7.7 & 7.7 & 7.8 & 7.8 & 7.1 & 7.6 & 8.2 & 7.6 & 7.7 & 6.9 & 7.1 & 6.7 & 7.2 & 7.3 & 7.0 \\
\hline Salinity (\%o) & 28.7 & 31.0 & 32.1 & 32.5 & 33.5 & 32.0 & 34.2 & 38.4 & 31.8 & 31.7 & 26.4 & 28.8 & 37.2 & 39.2 & 40.4 & 34.6 & 37.8 & 38.5 \\
\hline $\mathrm{DO}\left(\mathrm{mg} \mathrm{l}^{-1}\right)$ & 5.4 & 5.1 & 5.0 & 4.3 & 5.4 & 6.0 & 5.0 & 3.5 & 5.5 & 6.2 & 4.9 & 6.0 & 5.8 & 5.2 & 6.1 & 5.6 & 5.7 & 6.0 \\
\hline
\end{tabular}




\section{Table 2 (on next page)}

Ecobiological observations from the three nesting sites of $T$ achypleus gigas at Pantai Balok during Phase-1 new moon

Table 2: Ecobiological observations from the three (I-III) nesting sites of $T$ achypleus gigas at Pantai Balok during Phase-1 (2009-2010) new moon surveys ( "-" no sample observed at the time of investigation) 


\begin{tabular}{|c|c|c|c|c|c|c|c|c|c|c|c|c|c|c|c|}
\hline & \multicolumn{9}{|c|}{2009} & \multicolumn{6}{|c|}{2010} \\
\hline & \multicolumn{3}{|c|}{ August } & \multicolumn{3}{|c|}{ October } & \multicolumn{3}{|c|}{ November } & \multicolumn{3}{|c|}{ March } & \multicolumn{3}{|c|}{ April } \\
\hline & I & II & III & I & II & III & I & II & III & I & II & III & I & II & III \\
\hline \multicolumn{16}{|l|}{ (A) Biology } \\
\hline Nest (nos.) & - & 1 & - & 2 & - & & 1 & & 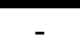 & 2 & - & - & 2 & - & \\
\hline Egg (nos.) & - & 104 & - & 385 & - & - & 92 & - & - & 158 & - & - & 320 & - & - \\
\hline Clutches (nos.) & - & 1 & - & 3 & - & - & 1 & 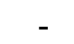 & - & 2 & - & - & 3 & - & - \\
\hline Male (nos.) & - & 2 & 1 & - & - & - & 1 & . & - & 1 & 4 & 1 & - & 2 & 1 \\
\hline Female (nos.) & 2 & - & - & - & - & . & 2 & . & - & . & 1 & 4 & 3 & - & - \\
\hline \multicolumn{16}{|l|}{ (B) Sediment } \\
\hline Mean & 1.9 & 1.3 & 1.3 & 1.2 & 2.1 & 1.7 & 1.2 & 2.4 & 1.9 & 1.1 & 2.1 & 2.2 & 1.1 & 1.9 & 1.9 \\
\hline Sorting $(\sigma \varphi)$ & 1.0 & 1.0 & 1.2 & 1.0 & 0.7 & 1.4 & 0.9 & 0.6 & 1.5 & 1.1 & 0.8 & 1.1 & 1.1 & 1.0 & 1.0 \\
\hline Skewness $(S K \varphi)$ & 0.3 & 0.1 & 0.0 & 0.1 & 0.3 & 0.3 & 0.0 & 0.2 & 0.5 & 0.0 & 0.1 & 0.5 & 0.0 & 0.1 & 0.5 \\
\hline Kurtc & 3.1 & 3.3 & 2.3 & 2.7 & 4.0 & 2.3 & 2.4 & 4.5 & 2.3 & 2.7 & 3.7 & 2.9 & 3.1 & 3.4 & 3.3 \\
\hline Gravel (\%) & 2.0 & 2.4 & 2.2 & 2.8 & 0.4 & 0.8 & 2.8 & 0.1 & 0.4 & 2.3 & 0.4 & 2.0 & 1.9 & 0.5 & 2.8 \\
\hline Sand (\%) & 93.2 & 95.9 & 94.8 & 93.5 & 98.4 & 95.0 & 93.9 & 99.6 & 94.8 & 94.9 & 97.9 & 94.1 & 94.6 & 96.9 & 93.1 \\
\hline Silt \& Clay (\%) & 4.8 & 1.8 & 3.0 & 3.7 & 1.2 & 4.2 & 3.3 & 0.3 & 4.7 & 2.9 & 1.7 & 3.9 & 3.5 & 2.6 & 4.2 \\
\hline $0.125 \mathrm{~mm}(\%)$ & 4.1 & 1.8 & 2.1 & 2.3 & 5.4 & 3.7 & 1.8 & 5.8 & 4.2 & 1.6 & 3.3 & 2.8 & 2.7 & 4.2 & 3.0 \\
\hline $0.180 \mathrm{~mm}(\%)$ & 15.3 & 10.0 & 11.4 & 13.7 & 14.6 & 14.7 & 11.9 & 15.8 & 16.0 & 11.8 & 14.0 & 14.1 & 11.9 & 14.7 & 13.0 \\
\hline $0.250 \mathrm{~mm} \mathrm{( \% )}$ & 21.9 & 19.4 & 19.7 & 20.0 & 20.2 & 23.9 & 19.7 & 21.5 & 26.3 & 19.6 & 23.2 & 21.6 & 18.5 & 20.4 & 18.7 \\
\hline Moisture depth $(\mathrm{cm})$ & 3.7 & 5.1 & 4.5 & 3.7 & 3.0 & 3.1 & 3.1 & 2.3 & 2.3 & 5.9 & 5.9 & 6.3 & 6.2 & 6.5 & 6.5 \\
\hline Temperature $\left({ }^{\circ} \mathrm{C}\right)$ & 32.6 & 32.4 & 32.5 & 30.0 & 30.2 & 30.5 & 29.3 & 29.3 & 29.5 & 29.9 & 30.0 & 30.2 & 32.3 & 32.3 & 32.5 \\
\hline $\mathrm{pH}$ & 6.2 & 6.2 & 6.1 & 6.2 & 6.3 & 6.4 & 6.5 & 6.7 & 6.7 & 6.0 & 5.8 & 5.9 & 5.5 & 5.4 & 5.3 \\
\hline \multicolumn{16}{|l|}{ (C) Water } \\
\hline Temperature $\left({ }^{\circ} \mathrm{C}\right)$ & 29.7 & 29.6 & 29.5 & 31.1 & 31.3 & 31.3 & 31.0 & 31.2 & 31.4 & 30.3 & 30.2 & 30.3 & 31.6 & 31.3 & 31.0 \\
\hline $\mathrm{pH}$ & 7.7 & 7.6 & 7.7 & 7.6 & 7.2 & 7.6 & 8.0 & 7.4 & 7.7 & 7.0 & 7.2 & 6.8 & 7.1 & 7.5 & 7.3 \\
\hline Sali & 30.6 & 32.3 & 32.1 & 35.4 & 37.1 & 31.9 & 32.9 & 32.1 & 30.2 & 35.9 & 38.6 & 39.4 & 36.6 & 35.4 & 36.7 \\
\hline $\mathrm{DO}\left(\mathrm{mg} \mathrm{l}^{-1}\right)$ & 4.8 & 5.2 & 5.5 & 4.6 & 4.2 & 5.0 & 5.6 & 4.2 & 5.8 & 5.7 & 5.5 & 6.0 & 5.9 & 6.0 & 5.7 \\
\hline
\end{tabular}




\section{Table 3(on next page)}

Ecobiological observations from the three nesting sites of $T$ achypleus gigas at Pantai Balok during Phase-2 full moon

Table 3: Ecobiological observations from the three (I-III) nesting sites of $T$ achypleus gigas at Pantai Balok during Phase-2 (2010-2011) full moon surveys ( "-" no sample observed at the time of investigation) 
1

\begin{tabular}{|c|c|c|c|c|c|c|c|c|c|c|c|c|c|c|c|c|c|c|c|c|c|c|c|c|}
\hline & \multicolumn{12}{|c|}{2010} & \multicolumn{12}{|c|}{2011} \\
\hline & \multicolumn{3}{|c|}{ June } & \multicolumn{3}{|c|}{ July } & \multicolumn{3}{|c|}{ August } & \multicolumn{3}{|c|}{ October } & \multicolumn{3}{|c|}{ March } & \multicolumn{3}{|c|}{ April } & \multicolumn{3}{|c|}{ May } & \multicolumn{3}{|c|}{ June } \\
\hline & I & II & III & I & II & III & I & II & III & I & II & III & I & II & III & I & II & III & I & II & III & I & II & III \\
\hline \multicolumn{25}{|l|}{ (A) Biology } \\
\hline Nest (nos.) & - & - & - & - & - & 2 & - & 2 & - & - & - & - & 3 & - & - & 1 & - & 1 & - & - & - & - & - & 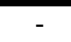 \\
\hline $\operatorname{Egg}$ (nos.) & - & - & - & - & - & 581 & - & 455 & - & - & - & - & 556 & - & - & 342 & - & 18 & - & - & - & - & - & - \\
\hline Clutches (nos.) & - & - & - & - & - & 3 & - & 2 & - & - & - & - & 3 & - & - & 1 & - & 1 & - & - & - & - & - & - \\
\hline Male (nos.) & - & 1 & 1 & - & 3 & - & - & 2 & - & - & 1 & - & 2 & - & - & 1 & - & - & - & - & 1 & - & - & 1 \\
\hline Female (nos.) & - & 1 & 1 & - & 2 & - & - & 1 & - & - & - & - & - & - & - & - & - & - & - & - & 1 & - & - & 1 \\
\hline \multicolumn{25}{|l|}{ (B) Sediment } \\
\hline Mean $(X \varphi)$ & 1.9 & 1.8 & 1.9 & 1.7 & 1.7 & 2.1 & 1.2 & 1.6 & 0.6 & 0.0 & 0.0 & 0.0 & 2.0 & 2.0 & 1.6 & 2.4 & 2.6 & 2.3 & 2.2 & 2.2 & 2.3 & 2.2 & 2.2 & 2.2 \\
\hline Sorting $(\sigma \varphi)$ & 1.1 & 1.1 & 1.1 & 1.0 & 1.0 & 0.9 & 1.4 & 1.1 & 1.3 & 0.5 & 0.5 & 0.6 & 0.9 & 1.1 & 1.2 & 0.5 & 0.5 & 0.5 & 0.6 & 0.6 & 0.6 & 0.7 & 0.7 & 0.8 \\
\hline Skewness $(S K \varphi)$ & 1.7 & 1.6 & 1.6 & 1.1 & 0.7 & 1.8 & 0.1 & 0.7 & 0.5 & 1.4 & 0.9 & 2.1 & 1.9 & 1.4 & 0.8 & 2.4 & 2.5 & 2.2 & 2.6 & 2.6 & 2.7 & 3.1 & 2.9 & 2.5 \\
\hline Kurtosis $(K \varphi)$ & 5.5 & 5.1 & 5.3 & 4.5 & 3.9 & 6.8 & 3.5 & 3.6 & 2.5 & 6.5 & 4.9 & 8.8 & 7.3 & 5.3 & 2.7 & 19.8 & 20.5 & 17.4 & 14.6 & 14.0 & 14.0 & 15.4 & 13.3 & 10.7 \\
\hline Gravel (\%) & 5.0 & 5.2 & 4.3 & 3.1 & 1.9 & 1.4 & 7.7 & 3.2 & 10.2 & 0.6 & 0.7 & 0.5 & 2.3 & 3.0 & 3.2 & 0.3 & 0.3 & 0.3 & 1.3 & 0.9 & 0.6 & 1.3 & 1.7 & 2.1 \\
\hline Sand (\%) & 94.3 & 94.3 & 95.0 & 95.5 & 96.0 & 97.2 & 88.7 & 93.5 & 86.8 & 99.4 & 99.3 & 99.5 & 97.4 & 96.3 & 95.7 & 99.2 & 99.2 & 99.4 & 98.5 & 98.7 & 99.0 & 98.6 & 98.0 & 97.5 \\
\hline Silt \& Clay (\%) & 0.6 & 0.5 & 0.7 & 1.4 & 2.1 & 1.4 & 3.6 & 3.3 & 3.0 & 0.0 & 0.0 & 0.0 & 0.4 & 0.8 & 1.1 & 0.5 & 0.5 & 0.3 & 0.3 & 0.3 & 0.4 & 0.1 & 0.2 & 0.3 \\
\hline $0.125 \mathrm{~mm}(\%)$ & 18.8 & 17.1 & 18.5 & 13.9 & 9.6 & 11.9 & 5.9 & 7.7 & 2.6 & 0.1 & 0.1 & 0.2 & 14.3 & 14.8 & 13.3 & 17.6 & 16.2 & 11.7 & 9.3 & 8.3 & 7.8 & 11.4 & 10.7 & 9.7 \\
\hline $0.180 \mathrm{~mm}(\%)$ & 28.5 & 26.1 & 27.8 & 28.4 & 29.6 & 60.5 & 25.7 & 26.3 & 18.6 & 0.3 & 0.2 & 0.6 & 47.5 & 43.7 & 34.0 & 66.1 & 62.9 & 66.7 & 63.4 & 65.7 & 70.6 & 71.5 & 69.3 & 64.8 \\
\hline $0.250 \mathrm{~mm}(\%)$ & 41.3 & 40.5 & 37.7 & 26.5 & 15.9 & 7.4 & 14.8 & 16.5 & 9.3 & 2.0 & 0.3 & 3.9 & 18.5 & 15.2 & 9.9 & 6.4 & 10.6 & 12.8 & 16.6 & 13.7 & 11.3 & 8.3 & 10.3 & 12.0 \\
\hline $\begin{array}{l}\text { Moisture depth } \\
(\mathrm{cm})\end{array}$ & 6.3 & 5.2 & 6.7 & 4.3 & 4.8 & 6.1 & 3.6 & 4.4 & 5.7 & 3.7 & 4.1 & 5.2 & 2.5 & 3.7 & 3.2 & 2.8 & 4.3 & 2.7 & 4.3 & 3.2 & 2.5 & 4.8 & 3.6 & 3.1 \\
\hline $\begin{array}{l}\text { Temperature } \\
\left({ }^{\circ} \mathrm{C}\right)\end{array}$ & 34.4 & 32.3 & 32.7 & 32.5 & 31.8 & 31.6 & 32.8 & 32.4 & 32.2 & 31.3 & 30.7 & 31.2 & 36.5 & 36.1 & 35.9 & 36.3 & 36.3 & 36.5 & 35.3 & 35.7 & 35.5 & 33.8 & 33.6 & 33.8 \\
\hline $\mathrm{pH}$ & 6.6 & 6.2 & 6.3 & 6.1 & 6.1 & 6.0 & 6.5 & 6.3 & 6.5 & 6.4 & 6.4 & 6.4 & 6.5 & 6.6 & 6.5 & 4.1 & 4.2 & 4.1 & 3.5 & 3.4 & 3.4 & 4.2 & 4.2 & 4.0 \\
\hline $\begin{array}{l}\text { Total Organic } \\
\text { Carbon }(\%)\end{array}$ & 0.2 & 0.2 & 0.2 & 0.1 & 0.1 & 0.2 & 0.1 & 0.1 & 0.1 & 0.2 & 0.2 & 0.2 & 0.1 & 0.1 & 0.2 & 0.1 & 0.1 & 0.1 & 0.1 & 0.2 & 0.1 & 0.1 & 0.2 & 0.2 \\
\hline $\mathrm{Cd}\left(\mathrm{mg} \mathrm{kg}^{-1}\right)$ & 4.6 & 3.3 & 5.4 & 4.4 & 3.6 & 4.0 & 3.9 & 3.6 & 3.3 & 1.9 & 2.5 & 1.5 & 5.5 & 5.7 & 5.2 & 6.6 & 7.0 & 6.0 & 5.5 & 3.7 & 2.0 & 6.2 & 4.1 & 1.8 \\
\hline $\mathrm{Cr}\left(\mathrm{mg} \mathrm{kg}^{-1}\right)$ & 30.9 & 27.4 & 31.0 & 29.0 & 27.6 & 27.0 & 26.7 & 24.0 & 22.7 & 19.9 & 21.5 & 20.6 & 33.0 & 31.2 & 25.3 & 29.7 & 29.6 & 23.8 & 25.8 & 23.1 & 21.3 & 24.1 & 25.5 & 26.0 \\
\hline $\mathrm{Cu}\left(\mathrm{mg} \mathrm{kg}^{-1}\right)$ & 6.6 & 8.7 & 3.8 & 6.2 & 8.8 & 8.9 & 17.3 & 15.0 & 15.3 & 7.1 & 7.2 & 7.7 & 2.7 & 1.9 & 0.9 & 2.6 & 2.8 & 2.5 & 3.3 & 2.1 & 0.9 & 3.2 & 2.2 & 1.1 \\
\hline $\mathrm{Pb}\left(\mathrm{mg} \mathrm{kg}^{-1}\right)$ & 5.2 & 4.6 & 5.1 & 6.3 & 7.6 & 9.1 & 10.4 & 9.3 & 8.9 & 7.6 & 8.4 & 7.7 & 11.0 & 12.9 & 13.0 & 10.3 & 12.4 & 12.1 & 9.5 & 9.4 & 9.7 & 8.7 & 9.7 & 10.4 \\
\hline $\mathrm{Se}\left(\mathrm{mg} \mathrm{kg}^{-1}\right)$ & 9.8 & 8.3 & 10.3 & 8.1 & 6.0 & 9.3 & 14.4 & 11.2 & 13.9 & 8.3 & 8.6 & 8.9 & 14.0 & 14.3 & 12.6 & 17.0 & 18.4 & 16.4 & 6.2 & 6.3 & 6.6 & 14.8 & 15.6 & 15.9 \\
\hline $\mathrm{Zn}\left(\mathrm{mg} \mathrm{kg}^{-1}\right)$ & 32.8 & 29.5 & 32.6 & 27.2 & 22.5 & 23.9 & 32.2 & 27.5 & 28.7 & 18.0 & 18.7 & 19.3 & 21.6 & 20.7 & 17.0 & 20.7 & 22.3 & 19.7 & 15.6 & 14.9 & 14.8 & 17.8 & 18.8 & 19.2 \\
\hline \multicolumn{25}{|l|}{ (C) Water } \\
\hline $\begin{array}{l}\text { Temperature } \\
\left({ }^{\circ} \mathrm{C}\right)\end{array}$ & 29.4 & 29.5 & 29.5 & 29.5 & 29.6 & 29.5 & 30.0 & 30.0 & 29.8 & 29.8 & 29.6 & 29.6 & 30.4 & 30.2 & 30.3 & 29.8 & 29.9 & 29.7 & 30.3 & 30.4 & 30.4 & 30.0 & 30.1 & 30.1 \\
\hline $\mathrm{pH}$ & 7.8 & 7.5 & 7.2 & 7.3 & 7.6 & 7.5 & 7.6 & 7.8 & 7.4 & 7.1 & 7.5 & 7.1 & 6.7 & 6.2 & 5.9 & 6.9 & 6.5 & 6.3 & 8.1 & 7.7 & 7.5 & 8.8 & 8.4 & 8.2 \\
\hline Salinity (\%o) & 32.1 & 32.8 & 33.6 & 32.0 & 32.8 & 33.6 & 32.5 & 32.9 & 33.3 & 6.6 & 10.7 & 12.0 & 8.2 & 9.4 & 10.2 & 4.1 & 5.6 & 6.4 & 11.1 & 12.6 & 13.3 & 14.9 & 15.3 & 17.0 \\
\hline $\begin{array}{l}\text { Dissolved } \\
\text { Oxygen }\left(\mathrm{mg} \mathrm{l}^{-1}\right)\end{array}$ & 5.4 & 5.3 & 5.3 & 6.0 & 5.9 & 5.8 & 4.3 & 4.7 & 4.8 & 4.0 & 3.7 & 3.4 & 3.1 & 3.2 & 3.4 & 5.3 & 5.2 & 5.2 & 2.8 & 3.0 & 3.1 & 3.3 & 3.3 & 3.3 \\
\hline $\mathrm{NO}_{2}^{-}\left(\mathrm{mg} \mathrm{l}^{-1}\right)$ & 0.0 & 0.0 & 0.0 & 0.1 & 0.1 & 0.1 & 0.1 & 0.1 & 0.1 & 0.0 & 0.0 & 0.0 & 0.1 & 0.1 & 0.1 & 0.0 & 0.0 & 0.0 & 0.0 & 0.0 & 0.0 & 0.0 & 0.0 & 0.0 \\
\hline $\mathrm{NO}_{3}^{-}\left(\mathrm{mg} \mathrm{l}^{-1}\right)$ & 0.9 & 1.3 & 1.4 & 1.4 & 1.6 & 1.5 & 1.1 & 1.1 & 0.8 & 0.3 & 0.6 & 0.3 & 1.5 & 1.6 & 1.4 & 1.1 & 1.9 & 1.8 & 0.8 & 0.5 & 0.9 & 0.6 & 0.2 & 0.2 \\
\hline $\mathrm{PO}_{4}^{3-}\left(\mathrm{mg} \mathrm{l}^{-1}\right)$ & 0.3 & 0.3 & 0.3 & 0.3 & 0.3 & 0.3 & 0.4 & 0.4 & 0.4 & 0.3 & 0.3 & 0.4 & 0.4 & 0.4 & 0.4 & 0.1 & 0.1 & 0.1 & 0.4 & 0.4 & 0.4 & 0.4 & 0.4 & 0.4 \\
\hline $\mathrm{S}^{2-}\left(\mu \mathrm{g} \mathrm{l}^{-1}\right)$ & 1.3 & 1.7 & 1.0 & 4.0 & 4.7 & 6.0 & 11.7 & 7.0 & 12.7 & 15.0 & 9.0 & 12.7 & 31.3 & 28.7 & 29.7 & 68.0 & 66.0 & 63.3 & 14.3 & 12.7 & 14.0 & 27.3 & 29.0 & 26.3 \\
\hline $\mathrm{Chl}-a\left(\mathrm{mg} \mathrm{l}^{-1}\right)$ & 0.1 & 0.1 & 0.1 & 0.1 & 0.1 & 0.1 & 0.0 & 0.0 & 0.0 & 0.1 & 0.1 & 0.1 & 0.1 & 0.1 & 0.1 & 0.0 & 0.0 & 0.0 & 0.1 & 0.1 & 0.1 & 0.1 & 0.1 & 0.1 \\
\hline
\end{tabular}




\section{Table 4 (on next page)}

Ecobiological observations from the three nesting sites of $T$ achypleus gigas at Pantai Balok during Phase-3 full moon

Table 4: Ecobiological observations from the three (I-III) nesting sites of $T$ achypleus gigas at Pantai Balok during Phase-3 (2012-2013) full moon surveys ( "-" no sample observed at the time of investigation) 


\begin{tabular}{|c|c|c|c|c|c|c|c|c|c|c|c|c|c|c|c|c|c|c|c|c|c|}
\hline & \multicolumn{12}{|c|}{2012} & \multicolumn{9}{|c|}{2013} \\
\hline & \multicolumn{3}{|c|}{ May } & \multicolumn{3}{|c|}{ June } & \multicolumn{3}{|c|}{ July } & \multicolumn{3}{|c|}{ August } & \multicolumn{3}{|c|}{ February } & \multicolumn{3}{|c|}{ March } & \multicolumn{3}{|c|}{ April } \\
\hline & I & II & III & I & II & III & I & II & III & I & II & III & $\mathrm{I}$ & II & III & $\mathrm{I}$ & II & III & $\mathrm{I}$ & II & III \\
\hline \multicolumn{22}{|l|}{ (A) Biology } \\
\hline Nest (nos.) & - & 6 & - & - & - & - & 8 & 4 & - & 1 & - & - & 2 & - & - & - & 1 & 1 & - & 1 & - \\
\hline Egg (nos.) & - & 868 & - & - & - & - & 1074 & 613 & - & 254 & - & - & 80 & - & - & - & 108 & 314 & - & 32 & - \\
\hline Clutches (nos.) & - & 5 & - & - & - & - & 10 & 6 & - & 2 & - & - & 3 & - & - & - & 1 & 3 & - & 1 & - \\
\hline Male (nos.) & 1 & 2 & - & - & 2 & - & 1 & 3 & 1 & - & - & - & 1 & - & - & - & - & - & - & 1 & 1 \\
\hline Female (nos.) & - & 1 & 1 & - & - & 1 & - & - & 2 & - & - & - & - & - & - & - & - & - & - & 1 & - \\
\hline \multicolumn{22}{|l|}{ (B) Sediment } \\
\hline Mean $(X \varphi)$ & 2.5 & 2.5 & 2.5 & 2.4 & 2.5 & 2.6 & 2.4 & 2.4 & 2.3 & 2.4 & 2.4 & 2.3 & 2.5 & 2.4 & 2.5 & 2.4 & 2.4 & 2.4 & 2.6 & 2.6 & 2.6 \\
\hline Sorting $(\sigma \varphi)$ & 0.6 & 0.7 & 0.6 & 0.9 & 0.9 & 0.8 & 0.8 & 1.0 & 0.9 & 0.8 & 0.9 & 0.9 & 0.6 & 0.7 & 0.5 & 0.7 & 0.8 & 0.6 & 0.5 & 0.6 & 0.4 \\
\hline Skewness $(S K \varphi)$ & -2.7 & -2.8 & -2.8 & -2.7 & -2.6 & -3.1 & -2.7 & -2.2 & -2.2 & -2.6 & -2.5 & -2.6 & -2.0 & -1.8 & -1.1 & -2.2 & -2.3 & -2.2 & -2.1 & -2.3 & -1.8 \\
\hline Kurtosis $(K \varphi)$ & 14.9 & 14.0 & 15.7 & 11.3 & 10.8 & 14.6 & 11.7 & 8.4 & 7.8 & 11.2 & 9.9 & 10.4 & 10.7 & 8.3 & 8.6 & 9.9 & 10.4 & 12.3 & 13.3 & 12.6 & 13.8 \\
\hline Gravel (\%) & 0.4 & 1.8 & 0.4 & 3.4 & 5.1 & 2.4 & 2.7 & 3.3 & 2.0 & 2.2 & 2.7 & 2.8 & 0.4 & 0.6 & 0.2 & 0.7 & 1.8 & 0.7 & 0.4 & 0.5 & 0.2 \\
\hline Sand $(\%)$ & 99.4 & 97.6 & 99.1 & 96.3 & 94.1 & 97.0 & 96.8 & 96.0 & 97.6 & 97.4 & 96.5 & 96.8 & 99.1 & 98.3 & 99.4 & 98.5 & 97.3 & 99.1 & 99.2 & 97.9 & 99.4 \\
\hline Silt \& Clay (\%) & 0.2 & 0.6 & 0.5 & 0.4 & 0.8 & 0.6 & 0.4 & 0.7 & 0.4 & 0.4 & 0.8 & 0.4 & 0.5 & 1.2 & 0.3 & 0.8 & 0.9 & 0.3 & 0.5 & 1.7 & 0.4 \\
\hline $0.125 \mathrm{~mm}(\%)$ & 40.7 & 37.5 & 39.4 & 34.9 & 41.9 & 46.6 & 39.2 & 34.6 & 36.0 & 35.4 & 37.2 & 34.0 & 29.9 & 28.5 & 29.5 & 37.2 & 35.4 & 26.7 & 39.9 & 37.7 & 39.3 \\
\hline $0.180 \mathrm{~mm}(\%)$ & 40.8 & 44.2 & 41.1 & 40.0 & 30.1 & 30.3 & 36.1 & 32.9 & 37.0 & 40.3 & 33.2 & 41.4 & 39.8 & 34.5 & 50.3 & 35.7 & 35.2 & 49.6 & 39.8 & 32.2 & 44.8 \\
\hline $0.250 \mathrm{~mm}(\%)$ & 7.7 & 7.5 & 7.6 & 10.5 & 5.1 & 4.2 & 7.8 & 9.3 & 7.2 & 8.2 & 7.9 & 9.1 & 11.3 & 13.0 & 10.6 & 8.6 & 9.3 & 13.6 & 9.0 & 8.5 & 5.5 \\
\hline Mois & 6.0 & 6.1 & 6.8 & 4.9 & 5.0 & 4.4 & 7.1 & 6.4 & 7.5 & 6.3 & 6.4 & 9.1 & 8.4 & 8.4 & 7.4 & 6.2 & 6.2 & 6.3 & 10.1 & 10.2 & 10.6 \\
\hline Temperature $\left({ }^{\circ} \mathrm{C}\right)$ & 30.0 & 28.1 & 28.9 & 31.7 & 32.8 & 32.3 & 28.6 & 32.4 & 33.5 & 33.8 & 32.5 & 31.4 & 30.5 & 28.8 & 29.4 & 33.5 & 33.8 & 33.7 & 39.1 & 37.3 & 36.6 \\
\hline $\mathrm{pH}$ & 5.9 & 5.8 & 6.1 & 6.8 & 6.5 & 6.8 & 4.0 & 5.4 & 4.6 & 3.0 & 3.8 & 2.8 & 5.6 & 5.6 & 5.8 & 4.9 & 4.9 & 4.9 & 2.8 & 3.2 & 4.0 \\
\hline $\begin{array}{l}\text { Total Organic Carbon } \\
(\%)\end{array}$ & 0.1 & 0.2 & 0.2 & 0.2 & 0.2 & 0.1 & 0.2 & 0.1 & 1 & 0.2 & 0.1 & 1 & 0.1 & 0.1 & 0.1 & 0.1 & 0.1 & 0.1 & 0.1 & 0.0 & 0.0 \\
\hline $\mathrm{Cd}\left(\mathrm{mg} \mathrm{kg}^{-1}\right)$ & 15.7 & 13.3 & 2.7 & 18.5 & 16.4 & 11.9 & 26.7 & 16.8 & 14.7 & 9.3 & 11.1 & 15.5 & 9.9 & 15.4 & 8.0 & 20.0 & 16.1 & 8.1 & 21.8 & 9.6 & 13.3 \\
\hline $\mathrm{Cr}\left(\mathrm{mg} \mathrm{kg}^{-1}\right)$ & 28.8 & 17.0 & 17.9 & 37.7 & 10.7 & 13.5 & 22.4 & 43.7 & 10.7 & 11.0 & 9.6 & 15.6 & 13.7 & 12.2 & 13.8 & 33.3 & 21.6 & 29.0 & 16.0 & 29.3 & 16.0 \\
\hline $\mathrm{Cu}\left(\mathrm{mg} \mathrm{kg}^{-1}\right)$ & 2.9 & 2.2 & 2.4 & 2.2 & 2.3 & 1.6 & 2.1 & 3.7 & 2.1 & 5.9 & 2.5 & 4.0 & 2.5 & 4.3 & 2.9 & 10.1 & 3.4 & 7.2 & 19.0 & 7.1 & 14.7 \\
\hline $\mathrm{Pb}\left(\mathrm{mg} \mathrm{kg}^{-1}\right)$ & 6.4 & 7.8 & 5.1 & 5.6 & 7.4 & 4.9 & 4.1 & 4.7 & 4.8 & 8.3 & 8.3 & 10.8 & 23.3 & 12.7 & 19.1 & 20.7 & 12.9 & 16.2 & 20.7 & 13.5 & 16.8 \\
\hline $\mathrm{Se}\left(\mathrm{mg} \mathrm{kg}^{-1}\right)$ & 29.4 & 32.1 & 18.2 & 27.8 & 26.3 & 14.2 & 27.4 & 28.0 & 17.0 & 18.2 & 19.9 & 20.9 & 15.5 & 15.2 & 28.0 & 36.6 & 23.4 & 10.1 & 21.3 & 28.0 & 19.7 \\
\hline $\mathrm{Zn}\left(\mathrm{mg} \mathrm{kg}^{-1}\right)$ & 19.0 & 20.8 & 15.0 & 14.6 & 19.2 & 14.6 & 12.3 & 14.0 & 14.1 & 20.6 & 23.5 & 27.5 & 23.8 & 23.2 & 23.6 & 41.6 & 28.9 & 30.0 & 26.8 & 26.3 & 27.3 \\
\hline \multicolumn{22}{|l|}{ (C) Water } \\
\hline Temperature $\left({ }^{\circ} \mathrm{C}\right)$ & 27.6 & 27.6 & 27.5 & 29.9 & 29.6 & 30.1 & 30.9 & 31.3 & 30.7 & 30.0 & 30.1 & 30.6 & 28.5 & 28.7 & 27.7 & 30.8 & 31.1 & 30.9 & 32.8 & 31.6 & 30.6 \\
\hline $\mathrm{pH}$ & 6.2 & 6.5 & 6.6 & 8.4 & 8.4 & 8.4 & 8.0 & 8.1 & 7.6 & 7.9 & 8.4 & 8.4 & 7.9 & 7.7 & 7.4 & 8.6 & 8.7 & 8.7 & 8.2 & 7.9 & 7.4 \\
\hline Salinity (\%o) & 3.1 & 2.7 & 2.3 & 33.3 & 33.4 & 33.3 & 34.5 & 34.5 & 34.6 & 30.0 & 31.0 & 31.2 & 3.7 & 3.9 & 5.4 & 20.9 & 21.7 & 21.7 & 16.9 & 15.0 & 16.7 \\
\hline $\begin{array}{l}\text { Dissolved Oxygen (mg } \\
\left.\mathrm{l}^{-1}\right)\end{array}$ & 2.8 & 3.2 & 4.1 & 5.3 & 5.1 & 5.6 & 6.8 & 5.4 & 6.7 & 7.8 & 5.8 & 9.1 & 7.6 & 5.0 & 7.9 & 5.3 & 6.4 & 4.5 & 4.6 & 6.0 & 5.5 \\
\hline $\mathrm{NO}_{2}^{-}\left(\mathrm{mg} \mathrm{l}^{-1}\right)$ & 0.0 & 0.0 & 0.0 & 0.0 & 0.0 & 0.0 & 0.0 & 0.0 & 0.0 & 0.0 & 0.0 & 0.0 & 0.1 & 0.1 & 0.0 & 0.0 & 0.1 & 0.0 & 0.1 & 0.1 & 0.1 \\
\hline $\mathrm{NO}_{3}^{-}\left(\mathrm{mg} \mathrm{l}^{-1}\right)$ & 0.2 & 0.3 & 0.3 & 0.7 & 1.4 & 0.3 & 0.7 & 0.3 & 0.6 & 3.4 & 0.6 & 0.7 & 0.4 & 0.6 & 0.7 & 2.9 & 1.7 & 2.4 & 0.6 & 0.7 & 0.9 \\
\hline $\mathrm{PO}_{4}^{3-}\left(\mathrm{mg} \mathrm{l}^{-1}\right)$ & 0.1 & 0.2 & 0.2 & 0.0 & 0.1 & 0.1 & 0.1 & 0.1 & 0.1 & 0.0 & 0.1 & 0.1 & 0.2 & 0.2 & 0.1 & 0.2 & 0.2 & 0.1 & 0.2 & 0.2 & 0.2 \\
\hline $\mathrm{S}^{2-}\left(\mu \mathrm{g} \mathrm{l}^{-1}\right)$ & 47.7 & 42.3 & 50.3 & 20.0 & 16.3 & 10.3 & 5.3 & 7.3 & 7.7 & 39.3 & 97.3 & 124.7 & 23.3 & 22.0 & 66.7 & 0.0 & 4.7 & 5.0 & 58.7 & 35.7 & 22.0 \\
\hline Chl- $a\left(\mathrm{mg} \mathrm{l}^{-1}\right)$ & 0.2 & 0.5 & 0.2 & 0.4 & 0.5 & 0.4 & 0.4 & 0.3 & 0.5 & 0.7 & 0.9 & 0.5 & 0.6 & 0.9 & 0.5 & 0.4 & 0.6 & 0.5 & 1.0 & 1.2 & 1.0 \\
\hline
\end{tabular}

1 


\section{Table 5 (on next page)}

Ecobiological observations from the three nesting sites of $T$ achypleus gigas at Pantai Balok during Phase-3 new moon

Table 5: Ecobiological observations from the three (I-III) nesting sites of $T$ achypleus gigas at Pantai Balok during Phase-3 (2012-2013) new moon surveys ( "-" no sample observed at the time of investigation) 


\begin{tabular}{|c|c|c|c|c|c|c|c|c|c|c|c|c|c|c|c|c|c|c|}
\hline & \multicolumn{9}{|c|}{2012} & \multicolumn{9}{|c|}{2013} \\
\hline & \multicolumn{3}{|c|}{ May } & \multicolumn{3}{|c|}{ June } & \multicolumn{3}{|c|}{ July } & \multicolumn{3}{|c|}{ February } & \multicolumn{3}{|c|}{ March } & \multicolumn{3}{|c|}{ May } \\
\hline & I & II & III & I & II & III & I & II & III & $\mathrm{I}$ & II & III & I & II & III & I & II & III \\
\hline \multicolumn{19}{|l|}{ (A) Biology } \\
\hline Nest (nos.) & - & - & - & - & 2 & - & - & - & - & - & 2 & - & 4 & - & - & - & - & - \\
\hline Egg (nos.) & - & - & - & - & 169 & - & - & - & - & - & 47 & - & 418 & - & - & - & - & - \\
\hline Clutches (nos.) & - & - & - & - & 4 & - & - & - & - & - & 2 & - & 6 & - & - & - & - & - \\
\hline Male (nos.) & - & 4 & - & - & 1 & - & - & 1 & - & - & - & - & - & - & - & - & - & - \\
\hline Female (nos.) & - & 1 & 1 & - & - & - & - & - & - & - & - & - & - & - & - & 1 & - & - \\
\hline \multicolumn{19}{|l|}{ (B) Sediment } \\
\hline Mean $(X \varphi)$ & 2.4 & 2.3 & 2.6 & 2.6 & 2.6 & 2.7 & 2.5 & 2.4 & 2.4 & 2.6 & 2.6 & 2.4 & 2.5 & 2.5 & 2.5 & 2.5 & 2.5 & 2.7 \\
\hline Sorting $(\sigma \varphi)$ & 0.8 & 0.8 & 0.6 & 0.5 & 0.6 & 0.5 & 0.7 & 0.8 & 0.7 & 0.5 & 0.7 & 0.6 & 0.6 & 0.7 & 0.5 & 0.5 & 0.6 & 0.5 \\
\hline Skewness $(S K \varphi)$ & -2.7 & -2.2 & -2.9 & -2.5 & -2.6 & -2.5 & -2.4 & -2.7 & -2.5 & -2.4 & -2.4 & -2.2 & -2.2 & -2.4 & -1.5 & -2.0 & -2.4 & -2.4 \\
\hline Kurtosis $(K \varphi)$ & 11.3 & 8.7 & 16.2 & 15.9 & 14.6 & 16.2 & 10.9 & 12.0 & 10.9 & 15.0 & 11.5 & 11.3 & 12.6 & 11.4 & 9.4 & 12.3 & 13.5 & 16.8 \\
\hline Gravel (\%) & 2.5 & 1.9 & 0.8 & 0.2 & 0.6 & 0.2 & 0.7 & 1.4 & 0.6 & 0.3 & 1.9 & 2.0 & 0.2 & 1.0 & 0.2 & 0.2 & 0.7 & 0.3 \\
\hline Sand (\%) & 97.1 & 97.7 & 98.4 & 99.5 & 98.5 & 98.8 & 98.9 & 98.1 & 99.1 & 99.1 & 97.1 & 97.8 & 99.2 & 98.1 & 99.3 & 99.0 & 98.6 & 99.3 \\
\hline Silt \& Clay (\%) & 0.3 & 0.4 & 0.8 & 0.4 & 0.9 & 1.0 & 0.4 & 0.5 & 0.3 & 0.6 & 1.0 & 0.3 & 0.6 & 0.9 & 0.5 & 0.8 & 0.6 & 0.4 \\
\hline $0.125 \mathrm{~mm}(\%)$ & 37.1 & 28.7 & 50.4 & 43.7 & 41.3 & 47.5 & 39.3 & 37.8 & 36.2 & 39.8 & 39.8 & 25.9 & 37.6 & 33.7 & 32.2 & 35.9 & 35.6 & 41.0 \\
\hline $0.180 \mathrm{~mm}(\%)$ & 38.6 & 41.4 & 29.3 & 37.1 & 34.8 & 30.3 & 37.2 & 36.6 & 43.3 & 38.4 & 32.2 & 47.7 & 39.0 & 33.4 & 43.0 & 41.0 & 40.5 & 33.4 \\
\hline $0.250 \mathrm{~mm}(\%)$ & 8.9 & 13.7 & 5.1 & 6.7 & 7.5 & 3.8 & 8.0 & 8.8 & 6.5 & 7.3 & 7.1 & 15.3 & 9.1 & 10.0 & 14.5 & 11.2 & 10.7 & 5.8 \\
\hline Moisture depth $(\mathrm{cm})$ & 5.8 & 6.1 & 6.0 & 6.3 & 4.3 & 4.5 & 6.6 & 9.2 & 9.9 & 3.7 & 4.4 & 3.2 & 6.6 & 6.6 & 6.8 & 9.0 & 8.7 & 8.8 \\
\hline Temperature $\left({ }^{\circ} \mathrm{C}\right)$ & 29.7 & 30.2 & 30.0 & 26.4 & 28.5 & 29.2 & 34.0 & 33.2 & 32.5 & 34.0 & 33.3 & 32.7 & 31.5 & 31.9 & 31.3 & 38.5 & 36.3 & 37.0 \\
\hline $\mathrm{pH}$ & 6.5 & 6.6 & 6.7 & 5.8 & 6.0 & 5.8 & 2.5 & 2.2 & 2.8 & 6.2 & 6.4 & 6.3 & 4.8 & 4.8 & 4.3 & 3.5 & 4.2 & 5.0 \\
\hline Total Organic Carbon (\%) & 0.1 & 0.2 & 0.2 & 0.3 & 0.3 & 0.3 & 0.1 & 0.1 & 0.1 & 0.2 & 0.1 & 0.1 & 0.1 & 0.1 & 0.1 & 0.0 & 0.1 & 0.1 \\
\hline $\mathrm{Cd}\left(\mathrm{mg} \mathrm{kg}^{-1}\right)$ & 14.0 & 8.8 & 13.8 & 22.7 & 16.4 & 14.0 & 16.1 & 12.0 & 21.9 & 2.3 & 8.9 & 10.4 & 7.3 & 11.0 & 1.0 & 9.6 & 5.7 & 39.8 \\
\hline $\mathrm{Cr}\left(\mathrm{mg} \mathrm{kg}^{-1}\right)$ & 20.3 & 12.5 & 30.3 & 23.9 & 14.3 & 18.9 & 14.4 & 15.5 & 9.2 & 28.8 & 25.1 & 14.8 & 13.1 & 13.3 & 16.2 & 38.1 & 16.4 & 26.4 \\
\hline $\mathrm{Cu}\left(\mathrm{mg} \mathrm{kg}^{-1}\right)$ & 5.7 & 3.0 & 4.1 & 2.8 & 1.7 & 4.5 & 3.3 & 2.6 & 1.6 & 4.3 & 5.0 & 2.1 & 3.2 & 4.9 & 2.9 & 9.8 & 5.4 & 5.0 \\
\hline $\mathrm{Pb}\left(\mathrm{mg} \mathrm{kg}^{-1}\right)$ & 8.9 & 6.0 & 6.7 & 6.8 & 6.4 & 9.1 & 5.7 & 4.8 & 4.7 & 27.7 & 26.8 & 21.4 & 24.8 & 15.1 & 37.8 & 21.0 & 23.1 & 37.1 \\
\hline $\mathrm{Se}\left(\mathrm{mg} \mathrm{kg}^{-1}\right)$ & 19.7 & 25.8 & 31.7 & 24.6 & 25.3 & 16.2 & 17.3 & 25.4 & 28.0 & 15.5 & 17.0 & 18.9 & 29.0 & 15.2 & 25.1 & 30.2 & 26.9 & 40.2 \\
\hline $\mathrm{Zn}\left(\mathrm{mg} \mathrm{kg}^{-1}\right)$ & 22.0 & 16.3 & 20.0 & 21.7 & 17.4 & 22.6 & 15.9 & 14.3 & 13.7 & 31.6 & 36.5 & 23.3 & 28.1 & 25.9 & 29.3 & 30.5 & 31.4 & 46.2 \\
\hline \multicolumn{19}{|l|}{ (C) Water } \\
\hline Temperature $\left({ }^{\circ} \mathrm{C}\right)$ & 29.8 & 29.7 & 29.8 & 29.5 & 29.7 & 29.5 & 29.1 & 28.9 & 31.2 & 30.3 & 29.6 & 30.0 & 29.4 & 29.6 & 29.5 & 30.5 & 31.4 & 31.6 \\
\hline $\mathrm{pH}$ & 6.0 & 6.2 & 6.4 & 8.3 & 8.3 & 8.4 & 7.0 & 7.5 & 8.1 & 8.1 & 8.1 & 7.6 & 8.1 & 8.1 & 7.8 & 8.7 & 8.6 & 8.0 \\
\hline Salinity (\%) & 36.0 & 35.9 & 36.8 & 33.2 & 33.0 & 33.1 & 27.4 & 28.4 & 33.5 & 4.1 & 4.4 & 5.4 & 12.4 & 12.6 & 13.9 & 22.0 & 23.2 & 26.2 \\
\hline Dissolved Oxygen $\left(\mathrm{mg} \mathrm{l}^{-1}\right)$ & 7.0 & 6.8 & 7.0 & 6.1 & 5.5 & 6.5 & 5.2 & 9.1 & 8.0 & 7.9 & 10.8 & 3.1 & 6.6 & 9.6 & 6.3 & 6.2 & 10.0 & 10.1 \\
\hline $\mathrm{NO}_{2}^{-}\left(\mathrm{mg} \mathrm{l}^{-1}\right)$ & 0.0 & 0.0 & 0.0 & 0.0 & 0.0 & 0.0 & 0.0 & 0.0 & 0.0 & 0.0 & 0.0 & 0.0 & 0.0 & 0.0 & 0.0 & 0.2 & 0.2 & 0.1 \\
\hline $\mathrm{NO}_{3}^{-}\left(\mathrm{mg} \mathrm{l}^{-1}\right)$ & 0.5 & 1.7 & 1.1 & 0.3 & 0.5 & 0.6 & 0.7 & 0.3 & 0.6 & 1.4 & 1.0 & 0.8 & 0.9 & 1.6 & 1.1 & 1.9 & 1.9 & 0.5 \\
\hline $\mathrm{PO}_{4}{ }^{3-}\left(\mathrm{mg} \mathrm{l}^{-1}\right)$ & 0.3 & 0.2 & 0.2 & 0.4 & 0.4 & 0.3 & 0.1 & 0.1 & 0.1 & 0.2 & 0.2 & 0.1 & 0.3 & 0.5 & 0.3 & 0.3 & 0.3 & 0.2 \\
\hline $\mathrm{S}^{2-}\left(\mu \mathrm{g} \mathrm{l}^{-1}\right)$ & 2.0 & 3.0 & 1.3 & 41.0 & 33.3 & 9.0 & 5.3 & 7.3 & 7.7 & 48.0 & 50.3 & 54.3 & 25.3 & 40.3 & 11.0 & 13.0 & 27.3 & 18.7 \\
\hline Chl- $a\left(\mathrm{mg} \mathrm{l}^{-1}\right)$ & 0.2 & 0.3 & 0.2 & 0.5 & 0.6 & 0.4 & 0.5 & 0.4 & 0.6 & 0.6 & 0.5 & 0.5 & 0.4 & 0.3 & 0.2 & 0.5 & 0.6 & 0.5 \\
\hline
\end{tabular}




\section{Table 6(on next page)}

Pair-wise statistical variationswithin biological and environmental parameters in relation to their study phases, seasons, sampling sites and lunar periods

Table 6: Pair-wise statistical variations ( $F$ values based on One-Way ANOVA) within biological and environmental parameters in relation to their study phases, seasons, sampling sites and lunar periods (Phase-1: 2009-2010, Phase-2: 2010-2011 and Phase-3: 2012-2013; SW: Southwest monsoon, NE: Northeast monsoon and IM: Inter-monsoon; TOC: Total Organic Carbon, DO: Dissolved Oxygen, $\mathrm{NO}_{2}{ }^{-}$: Nitrite, $\mathrm{NO}_{3}{ }^{-}$: Nitrate, $\mathrm{PO}_{4}{ }^{3-}$ : Phosphate, $\mathrm{S}^{2-}$ : Hydrogen Sulphide) (* $P<0.05$ ) ( "-“ Data not strong enough for statistical comparison; "\#" no Phase-1 observations) 


\begin{tabular}{|c|c|c|c|c|c|c|c|c|c|c|c|c|}
\hline & \multirow{2}{*}{$\begin{array}{c}\text { Biology } \\
\text { Egg/nest }\end{array}$} & \multicolumn{4}{|c|}{ Sediment } & \multicolumn{7}{|c|}{ Water } \\
\hline & & Gravel & $\begin{array}{c}\text { Silt \& } \\
\text { Clay }\end{array}$ & $\mathrm{pH}$ & TOC & Temperature & $\mathrm{pH}$ & DO & $\mathrm{NO}_{2}^{-}$ & $\mathrm{NO}_{3}{ }^{-}$ & $\mathrm{PO}_{4}^{3-}$ & Chl- $a$ \\
\hline Full moon vs. new moon & 1.96 & 0.47 & 0.16 & 0.05 & 0.06 & 0.002 & 0.24 & 1.59 & - & 0.25 & 0.04 & 0.002 \\
\hline Phase-1 vs. Phase-2 & 4.51 & 0.40 & - & . & $\#$ & 20.12 & $3400^{*}$ & $280^{*}$ & \# & $\#$ & \# & \# \\
\hline Phase-1 vs. Phase- 3 & 0.03 & 2.69 & $3721^{*}$ & $20.49^{*}$ & \# & 2.90 & $33.98 *$ & 2.09 & \# & \# & \# & \# \\
\hline Phase-2 vs. Phase- 3 & 2.04 & 1.85 & 2.08 & 3.0 & 3.0 & 0.13 & 61.79 & 3.09 & - & $280.33 *$ & 1.23 & 3.76 \\
\hline SW vs. NE & 0.45 & 0.79 & 0.06 & 1.24 & $81.0 *$ & 2.15 & 0.80 & 0.02 & 1.0 & $25.19 *$ & 0.03 & 0.02 \\
\hline SW vs. IM & 0.44 & 6.22 & 0.32 & 0.49 & 0.16 & 3.96 & 1.65 & 0.25 & 0 & 0.06 & 0.46 & 0.36 \\
\hline NE vs. IM & 0.01 & 1.43 & 0.11 & 1.83 & 0.25 & 2.19 & 0.04 & 0.02 & 1.0 & 9.63 & 1.34 & 0.27 \\
\hline Site-I vs. Site-II & 1.03 & 0.35 & 0.25 & 0.01 & 5.0 & 0.16 & 0.10 & 0.03 & - & 0.05 & 0.02 & 0.03 \\
\hline Site-I vs. Site-III & 0.66 & 0.06 & $6.9 \times 10^{-4}$ & 0.02 & 0.53 & 0.37 & 0.52 & 0.03 & - & 0.17 & 0.01 & $9.9 \times 10^{-4}$ \\
\hline Site-II vs. Site-III & 2.22 & 0.10 & 0.29 & 0.01 & 0.004 & 0.05 & 0.14 & $7.9 \times 10^{-4}$ & - & 0.20 & 0.03 & 0.05 \\
\hline
\end{tabular}

2 


\section{Table 7 (on next page)}

Metal induced Enrichment Factor and Geo-accumulation Index at the three nesting sites of $T$ achypleus gigas at Pantai Balok during Phase-2 survey

Table 7: Metal induced Enrichment Factor (EF) and Geo-accumulation Index ( $\left.{ }_{\text {geo }}\right)$ at the three (SI-III) nesting sites of T achypleus gigas at Pantai Balok during Phase-2 (2010-2011) survey (Cd - Cadmium, Cr - Chromium, Cu - Copper, Pb - Lead, Se - Selenium and Zn - Zinc) (The superscript letters in the Enrichment Factor shows - $D=$ deficiency to minimal enrichment, $\mathrm{M}=$ moderate enrichment, $\mathrm{S}=$ significant enrichment and, $\mathrm{E}=$ extremely high enrichment. The superscript letters in Geo-accumulation Index shows - $U$ = uncontaminated, $\mathrm{MC}=$ moderately contaminated, $\mathrm{MH}=$ moderate to heavy contamination, $\mathrm{H}=$ heavy contamination and, $\mathrm{HE}=$ heavy to extreme contamination) 


\begin{tabular}{|c|c|c|c|c|c|c|c|c|c|c|c|c|}
\hline \multicolumn{13}{|c|}{2010} \\
\hline & \multicolumn{3}{|c|}{ June } & \multicolumn{3}{|c|}{ July } & \multicolumn{3}{|c|}{ August } & \multicolumn{3}{|c|}{ October } \\
\hline & I & II & III & I & II & III & I & II & III & I & II & III \\
\hline \multicolumn{13}{|c|}{ (A) $\mathrm{EF}$} \\
\hline $\mathrm{Cd}$ & $85.6^{\mathrm{E}}$ & $55.3^{\mathrm{E}}$ & $112.9^{\mathrm{E}}$ & $104.8^{\mathrm{E}}$ & $90.1^{\mathrm{E}}$ & $86.3^{\mathrm{E}}$ & $144.9^{\mathrm{E}}$ & $130.4^{\mathrm{E}}$ & $123.3^{\mathrm{E}}$ & $104.6^{\mathrm{E}}$ & $138.6^{\mathrm{E}}$ & $82.8^{\mathrm{E}}$ \\
\hline $\mathrm{Cr}$ & $1.7^{\mathrm{D}}$ & $1.3^{\mathrm{D}}$ & $1.9^{\mathrm{D}}$ & $2.0^{\mathrm{M}}$ & $2.0^{\mathrm{M}}$ & $1.7^{\mathrm{D}}$ & $2.8^{\mathrm{M}}$ & $2.5^{\mathrm{M}}$ & $2.4^{\mathrm{M}}$ & $3.2^{\mathrm{M}}$ & $3.4^{\mathrm{M}}$ & $3.2^{\mathrm{M}}$ \\
\hline $\mathrm{Cu}$ & $0.5^{\mathrm{D}}$ & $0.6^{\mathrm{D}}$ & $0.3^{\mathrm{D}}$ & $0.6^{\mathrm{D}}$ & $0.9^{\mathrm{D}}$ & $0.8^{\mathrm{D}}$ & $2.6^{\mathrm{M}}$ & $2.2^{\mathrm{M}}$ & $2.3^{\mathrm{M}}$ & $1.6^{\mathrm{D}}$ & $1.6^{\mathrm{D}}$ & $1.7^{\mathrm{D}}$ \\
\hline $\mathrm{Pb}$ & $0.5^{\mathrm{D}}$ & $0.4^{\mathrm{D}}$ & $0.5^{\mathrm{D}}$ & $0.7^{\mathrm{D}}$ & $0.9^{\mathrm{D}}$ & $1.0^{\mathrm{D}}$ & $1.9^{\mathrm{D}}$ & $1.7^{\mathrm{D}}$ & $1.7^{\mathrm{D}}$ & $2.1^{\mathrm{M}}$ & $2.3^{\mathrm{M}}$ & $2.1^{\mathrm{M}}$ \\
\hline $\mathrm{Se}$ & $131.7^{\mathrm{E}}$ & $100.5^{\mathrm{E}}$ & $155.2^{\mathrm{E}}$ & $136.1^{\mathrm{E}}$ & $107.1^{\mathrm{E}}$ & $144.0^{\mathrm{E}}$ & $380.2^{\mathrm{E}}$ & $293.9^{\mathrm{E}}$ & $373.2^{\mathrm{E}}$ & $327.1^{\mathrm{E}}$ & $342.7^{\mathrm{E}}$ & $348.0^{\mathrm{E}}$ \\
\hline $\mathrm{Zn}$ & $0.9^{\mathrm{D}}$ & $0.7^{\mathrm{D}}$ & $1.0^{\mathrm{D}}$ & $1.0^{\mathrm{D}}$ & $0.8^{\mathrm{D}}$ & $0.8^{\mathrm{D}}$ & $1.8^{\mathrm{D}}$ & $1.5^{\mathrm{D}}$ & $1.6^{\mathrm{D}}$ & $1.5^{\mathrm{D}}$ & $1.6^{\mathrm{D}}$ & $1.6^{\mathrm{D}}$ \\
\hline \multicolumn{13}{|c|}{ (B) $I_{\text {geo }}$} \\
\hline $\mathrm{Cd}$ & $3.3^{\mathrm{H}}$ & $2.9^{\mathrm{MH}}$ & $3.6^{\mathrm{H}}$ & $3.3^{\mathrm{H}}$ & $3.0^{\mathrm{MH}}$ & $3.1^{\mathrm{H}}$ & $3.1^{\mathrm{H}}$ & $3.0^{\mathrm{MH}}$ & $2.9^{\mathrm{MH}}$ & $2.1^{\mathrm{MH}}$ & $2.5^{\mathrm{MH}}$ & $1.7^{\mathrm{MC}}$ \\
\hline $\mathrm{Cr}$ & $-2.1^{\mathrm{U}}$ & $-2.3^{\mathrm{U}}$ & $-2.1^{\mathrm{U}}$ & $-2.2^{\mathrm{U}}$ & $-2.3^{\mathrm{U}}$ & $-2.3^{\mathrm{U}}$ & $-2.3^{\mathrm{U}}$ & $-2.5^{\mathrm{U}}$ & $-2.6^{\mathrm{U}}$ & $-2.8^{\mathrm{U}}$ & $-2.6^{\mathrm{U}}$ & $-2.7^{\mathrm{U}}$ \\
\hline $\mathrm{Cu}$ & $-3.4^{\mathrm{U}}$ & $-3.0^{\mathrm{U}}$ & $-4.2^{\mathrm{U}}$ & $-3.4^{\mathrm{U}}$ & $-2.9^{\mathrm{U}}$ & $-2.9 \mathrm{U}$ & $-2.0^{\mathrm{U}}$ & $-2.2^{\mathrm{U}}$ & $-2.1^{\mathrm{U}}$ & $-3.3^{\mathrm{U}}$ & $-3.2^{\mathrm{U}}$ & $-3.1^{\mathrm{U}}$ \\
\hline $\mathrm{Pb}$ & $-2.5^{\mathrm{U}}$ & $-2.7^{\mathrm{U}}$ & $-2.5^{\mathrm{U}}$ & $-2.3^{\mathrm{U}}$ & $-2.0^{\mathrm{U}}$ & $-1.7^{\mathrm{U}}$ & $-1.5^{\mathrm{U}}$ & $-1.7^{\mathrm{U}}$ & $-1.8^{\mathrm{U}}$ & $-2.0^{\mathrm{U}}$ & $-1.8^{\mathrm{U}}$ & $-2.0^{\mathrm{U}}$ \\
\hline $\mathrm{Se}$ & $3.5^{\mathrm{H}}$ & $3.2^{\mathrm{H}}$ & $3.5^{\mathrm{H}}$ & $3.2^{\mathrm{H}}$ & $2.7^{\mathrm{MH}}$ & $3.4^{\mathrm{H}}$ & $4.0^{\mathrm{H}}$ & $3.6^{\mathrm{H}}$ & $4.0^{\mathrm{H}}$ & $3.2^{\mathrm{H}}$ & $3.2^{\mathrm{H}}$ & $3.3^{\mathrm{H}}$ \\
\hline $\mathrm{Zn}$ & $-2.1^{\mathrm{U}}$ & $-2.3^{\mathrm{U}}$ & $-2.1^{\mathrm{U}}$ & $-2.4^{\mathrm{U}}$ & $-2.7^{\mathrm{U}}$ & $-2.6^{\mathrm{U}}$ & $-2.1^{\mathrm{U}}$ & $-2.4^{\mathrm{U}}$ & $-2.3^{\mathrm{U}}$ & $-3.0^{\mathrm{U}}$ & $-2.9^{\mathrm{U}}$ & $-2.9^{\mathrm{U}}$ \\
\hline \multicolumn{13}{|c|}{2011} \\
\hline & \multicolumn{3}{|c|}{ March } & \multicolumn{3}{|c|}{ April } & \multicolumn{3}{|c|}{ May } & \multicolumn{3}{|c|}{ June } \\
\hline & I & II & III & I & II & III & I & II & III & I & II & III \\
\hline \multicolumn{13}{|c|}{ (C) $\mathrm{EF}$} \\
\hline $\mathrm{Cd}$ & $616.0^{\mathrm{E}}$ & $601.2^{\mathrm{E}}$ & $481.4^{\mathrm{E}}$ & $537.1^{\mathrm{E}}$ & $579.8^{\mathrm{E}}$ & $524.8^{\mathrm{E}}$ & $439.0^{\mathrm{E}}$ & $282.4^{\mathrm{E}}$ & $147.9^{\mathrm{E}}$ & $402.3^{\mathrm{E}}$ & $254.6^{\mathrm{E}}$ & $109.0^{\mathrm{E}}$ \\
\hline $\mathrm{Cr}$ & $10.4^{\mathrm{S}}$ & $9.4^{\mathrm{S}}$ & $6.7^{\mathrm{S}}$ & $6.9^{\mathrm{S}}$ & $7.0^{\mathrm{S}}$ & $5.9^{\mathrm{s}}$ & $5.9^{\mathrm{S}}$ & $5.1^{\mathrm{s}}$ & $4.5^{\mathrm{M}}$ & $4.4^{\mathrm{M}}$ & $4.5^{\mathrm{M}}$ & $4.4^{\mathrm{M}}$ \\
\hline $\mathrm{Cu}$ & $1.1^{\mathrm{D}}$ & $0.8^{\mathrm{D}}$ & $0.4^{\mathrm{D}}$ & $0.8^{\mathrm{D}}$ & $0.9^{\mathrm{D}}$ & $0.9^{\mathrm{D}}$ & $1.1^{\mathrm{D}}$ & $0.6^{\mathrm{D}}$ & $0.3^{\mathrm{D}}$ & $0.8^{\mathrm{D}}$ & $0.5^{\mathrm{D}}$ & $0.3^{\mathrm{D}}$ \\
\hline $\mathrm{Pb}$ & $6.2^{\mathrm{S}}$ & $4.2^{\mathrm{M}}$ & $6.1^{\mathrm{S}}$ & $4.2^{\mathrm{M}}$ & $5.1^{\mathrm{S}}$ & $5.2^{\mathrm{S}}$ & $3.8^{\mathrm{M}}$ & $3.6^{\mathrm{M}}$ & $3.6^{\mathrm{M}}$ & $2.8^{\mathrm{M}}$ & $3.0^{\mathrm{M}}$ & $3.1^{\mathrm{M}}$ \\
\hline $\mathrm{Se}$ & $1121.2^{\mathrm{E}}$ & $984.7^{\mathrm{E}}$ & $839.5^{\mathrm{E}}$ & $984.3^{\mathrm{E}}$ & $1091.7^{\mathrm{E}}$ & $1015.4^{\mathrm{E}}$ & $353.6^{\mathrm{E}}$ & $342.8^{\mathrm{E}}$ & $345.9^{\mathrm{E}}$ & $678.8^{\mathrm{E}}$ & $691.4^{\mathrm{E}}$ & $680.0^{\mathrm{E}}$ \\
\hline $\mathrm{Zn}$ & $3.6^{\mathrm{M}}$ & $2.5^{\mathrm{M}}$ & $2.4^{\mathrm{M}}$ & $2.5^{\mathrm{M}}$ & $2.8^{\mathrm{M}}$ & $2.6^{\mathrm{M}}$ & $1.9^{\mathrm{D}}$ & $1.7^{\mathrm{D}}$ & $1.6^{\mathrm{D}}$ & $1.7^{\mathrm{D}}$ & $1.7^{\mathrm{D}}$ & $1.7^{\mathrm{D}}$ \\
\hline \multicolumn{13}{|c|}{ (D) $\mathrm{I}_{\mathrm{geo}}$} \\
\hline $\mathrm{Cd}$ & $3.6^{\mathrm{H}}$ & $3.9^{\mathrm{H}}$ & $3.5^{\mathrm{H}}$ & $3.9^{\mathrm{H}}$ & $4.0^{\mathrm{H}}$ & $3.7^{\mathrm{H}}$ & $3.6^{\mathrm{H}}$ & $3.0^{\mathrm{MH}}$ & $2.2^{\mathrm{MH}}$ & $3.8^{\mathrm{H}}$ & $3.2^{\mathrm{H}}$ & $2.0^{\mathrm{MC}}$ \\
\hline $\mathrm{Cr}$ & $-2.0^{\mathrm{U}}$ & $-2.2^{\mathrm{U}}$ & $-2.4^{\mathrm{U}}$ & $-2.2^{\mathrm{U}}$ & $-2.2^{\mathrm{U}}$ & $-2.5^{\mathrm{U}}$ & $-2.4^{\mathrm{U}}$ & $-2.5^{\mathrm{U}}$ & $-2.7^{\mathrm{U}}$ & $-2.5^{\mathrm{U}}$ & $-2.4^{\mathrm{U}}$ & $-2.4^{\mathrm{U}}$ \\
\hline $\mathrm{Cu}$ & $-4.7^{\mathrm{U}}$ & $-4.7^{\mathrm{U}}$ & $-6.2^{\mathrm{U}}$ & $-4.7^{\mathrm{U}}$ & $-4.6^{\mathrm{U}}$ & $-4.7^{\mathrm{U}}$ & $-4.4^{\mathrm{U}}$ & $-5.0^{\mathrm{U}}$ & $-6.2^{\mathrm{U}}$ & $-4.4^{\mathrm{U}}$ & $-4.9^{\mathrm{U}}$ & $-6.0^{\mathrm{U}}$ \\
\hline $\mathrm{Pb}$ & $-1.4^{\mathrm{U}}$ & $-1.5^{\mathrm{U}}$ & $-1.2^{\mathrm{U}}$ & $-1.5^{\mathrm{U}}$ & $-1.3^{\mathrm{U}}$ & $-1.3^{\mathrm{U}}$ & $-1.7^{\mathrm{U}}$ & $-1.7^{\mathrm{U}}$ & $-1.6^{\mathrm{U}}$ & $-1.8^{\mathrm{U}}$ & $-1.6^{\mathrm{U}}$ & $-1.5^{\mathrm{U}}$ \\
\hline $\mathrm{Se}$ & $4.0^{\mathrm{H}}$ & $4.2^{\mathrm{HE}}$ & $3.8^{\mathrm{H}}$ & $4.2^{\mathrm{HE}}$ & $4.4^{\mathrm{HE}}$ & $4.2^{\mathrm{HE}}$ & $2.8^{\mathrm{MH}}$ & $2.8^{\mathrm{MH}}$ & $2.9^{\mathrm{MH}}$ & $4.0^{\mathrm{H}}$ & $4.1^{\mathrm{HE}}$ & $4.1^{\mathrm{HE}}$ \\
\hline
\end{tabular}




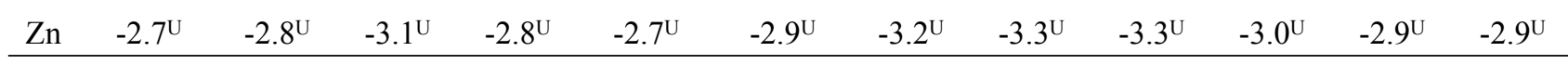




\section{Table 8(on next page)}

Metal induced Enrichment Factor and Geo-accumulation Index at the three nesting sites of $T$ achypleus gigas at Pantai Balok during Phase-3

Table 8: Metal induced Enrichment Factor (EF) and Geo-accumulation Index ( $\left.{ }_{\text {geo }}\right)$ at the three (SI-3) nesting sites of $T$ achypleus gigas at Pantai Balok during Phase-3 (2012-2013) survey (Cd - Cadmium, Cr - Chromium, Cu - Copper, Pb - Lead, Se - Selenium and Zn - Zinc) (“-“ no sample observed at the time of investigation. The superscript letters in the Enrichment Factor shows $-\mathrm{D}=$ deficiency to minimal enrichment, $\mathrm{M}=$ moderate enrichment, $\mathrm{S}=$ significant enrichment, $\mathrm{V}=$ very high enrichment and, $\mathrm{E}=$ extremely high enrichment. The superscript letters in Geo-accumulation Index shows - $\mathrm{U}=$ uncontaminated, $\mathrm{UM}=$ uncontaminated to moderately contaminated, $\mathrm{ME}=$ moderate contaminated, $\mathrm{MH}=$ moderate to heavy contamination, $\mathrm{H}=$ heavy contamination, $\mathrm{HE}=$ heavy to extreme contamination and, $\mathrm{EC}=$ extremely contaminated) 


\begin{tabular}{|c|c|c|c|c|c|c|c|c|c|c|c|c|c|c|c|c|c|c|c|c|c|c|c|c|}
\hline & \multicolumn{12}{|c|}{2012} & \multicolumn{12}{|c|}{2013} \\
\hline & \multicolumn{3}{|c|}{ May } & \multicolumn{3}{|c|}{ June } & \multicolumn{3}{|c|}{ July } & \multicolumn{3}{|c|}{ August } & \multicolumn{3}{|c|}{ Feb } & \multicolumn{3}{|c|}{ March } & \multicolumn{3}{|c|}{ April } & \multicolumn{3}{|c|}{ May } \\
\hline & I & II & III & I & II & III & I & II & III & I & II & III & I & II & III & I & II & III & I & II & III & I & II & III \\
\hline \multicolumn{25}{|c|}{ (A) EF for full moon observations } \\
\hline $\mathrm{Cd}$ & $296.5^{\mathrm{E}}$ & $199.4^{\mathrm{E}}$ & $81.6^{\mathrm{E}}$ & $523.6^{\mathrm{E}}$ & $364.4^{\mathrm{E}}$ & $339.5^{\mathrm{E}}$ & $737.3^{\mathrm{E}}$ & $408.9^{\mathrm{E}}$ & $416.6^{\mathrm{E}}$ & $213.3^{\mathrm{E}}$ & $216.2^{\mathrm{E}}$ & $292.4^{\mathrm{E}}$ & $193.0^{\mathrm{E}}$ & $269.6^{\mathrm{E}}$ & $168.6^{\mathrm{E}}$ & $215.0^{\mathrm{E}}$ & $231.5^{\mathrm{E}}$ & $149.7^{\mathrm{E}}$ & $372.1^{\mathrm{E}}$ & $156.0^{\mathrm{E}}$ & $258.2^{\mathrm{E}}$ & - & & - \\
\hline $\mathrm{Cr}$ & $1.5^{\mathrm{D}}$ & $0.7^{\mathrm{D}}$ & $1.5^{\mathrm{D}}$ & $3.0^{\mathrm{M}}$ & $0.7^{\mathrm{D}}$ & $1.1^{\mathrm{D}}$ & $1.8^{\mathrm{D}}$ & $3.1^{\mathrm{M}}$ & $0.9^{\mathrm{D}}$ & $0.7^{\mathrm{D}}$ & $0.5^{\mathrm{D}}$ & $0.8^{\mathrm{D}}$ & $0.8^{\mathrm{D}}$ & $0.6^{\mathrm{D}}$ & $0.8^{\mathrm{D}}$ & $0.9^{\mathrm{D}}$ & $0.9^{\mathrm{D}}$ & $1.3^{\mathrm{D}}$ & $0.8^{\mathrm{D}}$ & $1.3^{\mathrm{D}}$ & $0.9^{\mathrm{D}}$ & - & - & - \\
\hline $\mathrm{Cu}$ & $0.2^{\mathrm{D}}$ & $0.1^{\mathrm{D}}$ & $0.3^{\mathrm{D}}$ & $0.2^{\mathrm{D}}$ & $0.2^{\mathrm{D}}$ & $0.2^{\mathrm{D}}$ & $0.2^{\mathrm{D}}$ & $0.4^{\mathrm{D}}$ & $0.2^{\mathrm{D}}$ & $0.5^{\mathrm{D}}$ & $0.2^{\mathrm{D}}$ & $0.3^{\mathrm{D}}$ & $0.2^{\mathrm{D}}$ & $0.3^{\mathrm{D}}$ & $0.2^{\mathrm{D}}$ & $0.4^{\mathrm{D}}$ & $0.2^{\mathrm{D}}$ & $0.4^{\mathrm{D}}$ & $1.3^{\mathrm{D}}$ & $0.4^{\mathrm{D}}$ & $1.2^{\mathrm{D}}$ & - & - & - \\
\hline $\mathrm{Pb}$ & $0.6^{\mathrm{D}}$ & $0.6^{\mathrm{D}}$ & $0.8^{\mathrm{D}}$ & $0.8^{\mathrm{D}}$ & $0.8^{\mathrm{D}}$ & $0.7^{\mathrm{D}}$ & $0.6^{\mathrm{D}}$ & $0.6^{\mathrm{D}}$ & $0.7^{\mathrm{D}}$ & $0.9^{\mathrm{D}}$ & $0.8^{\mathrm{D}}$ & $1.0^{\mathrm{D}}$ & $2.3^{\mathrm{M}}$ & $1.1^{\mathrm{D}}$ & $2.0^{\mathrm{M}}$ & $1.0^{\mathrm{D}}$ & $0.9^{\mathrm{D}}$ & $1.3^{\mathrm{D}}$ & $1.7^{\mathrm{D}}$ & $1.1^{\mathrm{D}}$ & $1.7^{\mathrm{D}}$ & - & - & - \\
\hline $\mathrm{Se}$ & $396.9^{\mathrm{E}}$ & $345.7^{\mathrm{E}}$ & $390.0^{\mathrm{E}}$ & $555.9^{\mathrm{E}}$ & $418.0^{\mathrm{E}}$ & $290.9^{\mathrm{E}}$ & $547.2^{\mathrm{E}}$ & $490.1^{\mathrm{E}}$ & $343.3^{\mathrm{E}}$ & $292.1^{\mathrm{E}}$ & $280.8^{\mathrm{E}}$ & $287.9^{\mathrm{E}}$ & $216.9^{\mathrm{E}}$ & $190.4^{\mathrm{E}}$ & $419.8^{\mathrm{E}}$ & $287.8^{\mathrm{E}}$ & $239.9^{\mathrm{E}}$ & $121.6^{\mathrm{E}}$ & $253.5^{\mathrm{E}}$ & $311.5^{\mathrm{E}}$ & $279.1^{\mathrm{E}}$ & - & - & - \\
\hline $\mathrm{Zn}$ & $5.3^{\mathrm{s}}$ & $4.7^{\mathrm{S}}$ & $6.6^{\mathrm{S}}$ & $6.2^{\mathrm{S}}$ & $6.4^{\mathrm{S}}$ & $6.3^{\mathrm{s}}$ & $6.4^{\mathrm{S}}$ & $5.5^{\mathrm{s}}$ & $5.9^{\mathrm{s}}$ & $7.0^{\mathrm{s}}$ & $6.9^{\mathrm{s}}$ & $7.8^{\mathrm{S}}$ & $7.0^{\mathrm{s}}$ & $6.0^{\mathrm{s}}$ & $7.4^{\mathrm{s}}$ & $6.1^{\mathrm{s}}$ & $6.2^{\mathrm{S}}$ & $7.0^{\mathrm{s}}$ & $6.6^{\mathrm{S}}$ & $6.2^{\mathrm{s}}$ & $8.0^{\mathrm{S}}$ & - & - & - \\
\hline \multicolumn{25}{|c|}{ (B) EF for new moon observations } \\
\hline $\mathrm{Cd}$ & $266.3^{\mathrm{E}}$ & $210.4^{\mathrm{E}}$ & $290.6^{\mathrm{E}}$ & $544.4^{\mathrm{E}}$ & $359.6^{\mathrm{E}}$ & $317.7^{\mathrm{E}}$ & $432.4^{\mathrm{E}}$ & $309.2^{\mathrm{E}}$ & $634.1^{\mathrm{E}}$ & - & 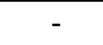 & 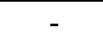 & $30.9^{\mathrm{V}}$ & $88.6^{\mathrm{E}}$ & $218.7^{\mathrm{E}}$ & $110.1^{\mathrm{E}}$ & $174.6^{\mathrm{E}}$ & $19.5^{\mathrm{S}}$ & - & - & & $114.9^{\mathrm{E}}$ & $57.9^{\mathrm{E}}$ & $572.1^{\mathrm{E}}$ \\
\hline $\mathrm{Cr}$ & $1.1^{\mathrm{D}}$ & $0.9^{\mathrm{D}}$ & $1.8^{\mathrm{D}}$ & $1.6^{\mathrm{D}}$ & $0.9^{\mathrm{D}}$ & $1.2^{\mathrm{D}}$ & $1.1^{\mathrm{D}}$ & $1.1^{\mathrm{D}}$ & $0.8^{\mathrm{D}}$ & - & - & - & $1.1^{\mathrm{D}}$ & $0.7^{\mathrm{D}}$ & $0.9^{\mathrm{D}}$ & $0.5^{\mathrm{D}}$ & $0.6^{\mathrm{D}}$ & $0.9^{\mathrm{D}}$ & . & - & - & $1.3^{\mathrm{D}}$ & $0.5^{\mathrm{D}}$ & $1.1^{\mathrm{D}}$ \\
\hline $\mathrm{Cu}$ & $0.4^{\mathrm{D}}$ & $0.3^{\mathrm{D}}$ & $0.3^{\mathrm{D}}$ & $0.3^{\mathrm{D}}$ & $0.1^{\mathrm{D}}$ & $0.4^{\mathrm{D}}$ & $0.4^{\mathrm{D}}$ & $0.3^{\mathrm{D}}$ & $0.2^{\mathrm{D}}$ & - & - & - & $0.2^{\mathrm{D}}$ & $0.2^{\mathrm{D}}$ & $0.2^{\mathrm{D}}$ & $0.2^{\mathrm{D}}$ & $0.3^{\mathrm{D}}$ & $0.2^{\mathrm{D}}$ & - & - & - & $0.5^{\mathrm{D}}$ & $0.2^{\mathrm{D}}$ & $0.3^{\mathrm{D}}$ \\
\hline $\mathrm{Pb}$ & $0.8^{\mathrm{D}}$ & $0.7^{\mathrm{D}}$ & $0.7^{\mathrm{D}}$ & $0.8^{\mathrm{D}}$ & $0.7^{\mathrm{D}}$ & $1.0^{\mathrm{D}}$ & $0.8^{\mathrm{D}}$ & $0.6^{\mathrm{D}}$ & $0.7^{\mathrm{D}}$ & - & - & - & $1.8^{\mathrm{D}}$ & $1.3^{\mathrm{D}}$ & $2.3^{\mathrm{M}}$ & $1.8^{\mathrm{D}}$ & $1.2^{\mathrm{D}}$ & $3.5^{\mathrm{D}}$ & - & - & - & $1.3^{\mathrm{D}}$ & $1.1^{\mathrm{D}}$ & $2.6^{\mathrm{M}}$ \\
\hline $\mathrm{Se}$ & $263.2^{\mathrm{E}}$ & $437.4^{\mathrm{E}}$ & $457.6^{\mathrm{E}}$ & $414.6^{\mathrm{E}}$ & $396.7^{\mathrm{E}}$ & $262.4^{\mathrm{E}}$ & $332.7^{\mathrm{E}}$ & $464.6^{\mathrm{E}}$ & $574.9^{\mathrm{E}}$ & - & . & - & $149.4^{\mathrm{E}}$ & $125.4^{\mathrm{E}}$ & $283.0^{\mathrm{E}}$ & $300.2^{\mathrm{E}}$ & $177.1^{\mathrm{E}}$ & $351.8^{\mathrm{E}}$ & . & - & - & $263.5^{\mathrm{E}}$ & $182.6^{\mathrm{E}}$ & $408.1^{\mathrm{E}}$ \\
\hline $\mathrm{Zn}$ & $6.2^{\mathrm{S}}$ & $6.0^{\mathrm{S}}$ & $6.1^{\mathrm{s}}$ & $7.7 \mathrm{~s}$ & $5.6^{\mathrm{S}}$ & $7.6^{\mathrm{S}}$ & $6.4^{\mathrm{S}}$ & $5.5^{\mathrm{s}}$ & $5.9^{\mathrm{S}}$ & 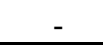 & 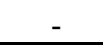 & 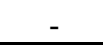 & $6.2^{\mathrm{S}}$ & $5.3^{\mathrm{s}}$ & $7.4^{\mathrm{S}}$ & $6.1^{\mathrm{s}}$ & $6.2^{\mathrm{s}}$ & $8.2^{\mathrm{s}}$ & - & - & & $5.6^{\mathrm{S}}$ & $4.5^{\mathrm{s}}$ & $9.7^{\mathrm{s}}$ \\
\hline \multicolumn{25}{|c|}{ (C) $I_{\mathrm{geo}}$ for full moon observations } \\
\hline $\mathrm{Cd}$ & $5.0^{\mathrm{HE}}$ & $4.8^{\mathrm{HE}}$ & $2.2^{\mathrm{MH}}$ & $5.3^{\mathrm{EC}}$ & $5.0^{\mathrm{HE}}$ & $4.6^{\mathrm{HE}}$ & $5.9^{\mathrm{EC}}$ & $5.2^{\mathrm{EC}}$ & $5.0^{\mathrm{EC}}$ & $4.3^{\mathrm{HE}}$ & $4.5^{\mathrm{HE}}$ & $5.1^{\mathrm{EC}}$ & $4.3^{\mathrm{HE}}$ & $4.6^{\mathrm{HE}}$ & $4.0^{\mathrm{HE}}$ & $5.5^{\mathrm{EC}}$ & $5.1^{\mathrm{EC}}$ & $3.9^{\mathrm{H}}$ & $5.3^{\mathrm{EC}}$ & $4.4^{\mathrm{HE}}$ & $4.8^{\mathrm{HE}}$ & & & - \\
\hline $\mathrm{Cr}$ & $-2.2^{\mathrm{U}}$ & $-3.0^{\mathrm{U}}$ & $-2.9^{\mathrm{U}}$ & $-1.8^{\mathrm{U}}$ & $-3.7^{\mathrm{U}}$ & $-3.3^{\mathrm{U}}$ & $-2.6^{\mathrm{U}}$ & $-1.6^{\mathrm{U}}$ & $-3.7^{\mathrm{U}}$ & $-3.6^{\mathrm{U}}$ & $-3.8^{\mathrm{U}}$ & $-3.1^{\mathrm{U}}$ & $-3.3^{\mathrm{U}}$ & $-3.5^{\mathrm{U}}$ & $-3.3^{\mathrm{U}}$ & $-2.1^{\mathrm{U}}$ & $-2.7^{\mathrm{U}}$ & $-2.3^{\mathrm{U}}$ & $-3.1^{\mathrm{U}}$ & $-2.2^{\mathrm{U}}$ & $-3.1^{\mathrm{U}}$ & - & - & - \\
\hline $\mathrm{Cu}$ & $-4.6^{\mathrm{U}}$ & $-4.9^{\mathrm{U}}$ & $-4.9^{\mathrm{U}}$ & $-5.0^{\mathrm{U}}$ & $-4.9^{\mathrm{U}}$ & $-5.4^{\mathrm{U}}$ & $-5.1^{\mathrm{U}}$ & $-4.4^{\mathrm{U}}$ & $-5.0^{\mathrm{U}}$ & $-3.5^{\mathrm{U}}$ & $-4.8^{\mathrm{U}}$ & $-4.1^{\mathrm{U}}$ & $-4.8^{\mathrm{U}}$ & $-4.0^{\mathrm{U}}$ & $-4.6^{\mathrm{U}}$ & $-2.8^{\mathrm{U}}$ & $-4.3^{\mathrm{U}}$ & $-3.3^{\mathrm{U}}$ & $-1.8^{\mathrm{U}}$ & $-3.3^{\mathrm{U}}$ & $-2.2^{\mathrm{U}}$ & - & - & - \\
\hline $\mathrm{Pb}$ & $-2.2^{\mathrm{U}}$ & $-1.9^{\mathrm{U}}$ & $-2.6^{\mathrm{U}}$ & $-2.4^{\mathrm{U}}$ & $-2.0^{\mathrm{U}}$ & $-2.6^{\mathrm{U}}$ & $-2.9^{\mathrm{U}}$ & $-2.7^{\mathrm{U}}$ & $-2.6^{\mathrm{U}}$ & $-1.9^{\mathrm{U}}$ & $-1.9^{\mathrm{U}}$ & $-1.5^{\mathrm{U}}$ & $-0.4^{\mathrm{U}}$ & $-1.2^{\mathrm{U}}$ & $-0.6^{\mathrm{U}}$ & $-0.6^{\mathrm{U}}$ & $-1.2^{\mathrm{U}}$ & $-0.9^{\mathrm{U}}$ & $-0.5^{\mathrm{U}}$ & $-1.2^{\mathrm{U}}$ & $-0.8^{\mathrm{U}}$ & - & - & - \\
\hline $\mathrm{Se}$ & $4.9^{\mathrm{HE}}$ & $5.1^{\mathrm{EC}}$ & $4.3^{\mathrm{HE}}$ & $4.8^{\mathrm{HE}}$ & $4.9^{\mathrm{HE}}$ & $3.9^{\mathrm{H}}$ & $4.9^{\mathrm{HE}}$ & $4.9^{\mathrm{HE}}$ & $4.2^{\mathrm{HE}}$ & $4.3^{\mathrm{HE}}$ & $3.5^{\mathrm{H}}$ & $4.5^{\mathrm{HE}}$ & $4.0^{\mathrm{HE}}$ & $4.0^{\mathrm{HE}}$ & $4.8^{\mathrm{HE}}$ & $5.2^{\mathrm{EC}}$ & $4.6^{\mathrm{HE}}$ & $3.4^{\mathrm{H}}$ & $4.5^{\mathrm{HE}}$ & $4.9^{\mathrm{HE}}$ & $4.4^{\mathrm{HE}}$ & - & - & - \\
\hline $\mathrm{Zn}$ & $-2.9^{\mathrm{U}}$ & $-2.8^{\mathrm{U}}$ & $-3.3^{\mathrm{U}}$ & $-3.3^{\mathrm{U}}$ & $-2.9^{\mathrm{U}}$ & $-3.3^{\mathrm{U}}$ & $-3.5^{\mathrm{U}}$ & $-3.3^{\mathrm{U}}$ & $-3.3^{\mathrm{U}}$ & $-2.8^{\mathrm{U}}$ & $-2.6^{\mathrm{U}}$ & $-2.4^{\mathrm{U}}$ & $-2.6^{\mathrm{U}}$ & $-2.6^{\mathrm{U}}$ & $-2.6^{\mathrm{U}}$ & $-1.8^{\mathrm{U}}$ & $-2.3^{\mathrm{U}}$ & $-2.3^{\mathrm{U}}$ & $-2.4^{\mathrm{U}}$ & $-2.4^{\mathrm{U}}$ & $-2.4^{\mathrm{U}}$ & . & 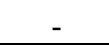 & . \\
\hline \multicolumn{25}{|c|}{ (D) $I_{\text {geo }}$ for new moon observations } \\
\hline $\mathrm{Cd}$ & $4.9^{\mathrm{HE}}$ & $4.1^{\mathrm{HE}}$ & $4.9^{\mathrm{HE}}$ & $5.6^{\mathrm{EC}}$ & $5.2^{\mathrm{EC}}$ & $4.6^{\mathrm{HE}}$ & $5.2^{\mathrm{EC}}$ & $4.7^{\mathrm{HE}}$ & $5.6^{\mathrm{EC}}$ & $\begin{array}{ll}- & \text { r }\end{array}$ & $\begin{array}{ll}- \\
-\end{array}$ & - & $2.2^{\mathrm{MH}}$ & $4.2^{\mathrm{HE}}$ & $4.2^{\mathrm{HE}}$ & $3.2^{\mathrm{H}}$ & $4.4^{\mathrm{HE}}$ & $1.1^{\mathrm{ME}}$ & & $\begin{array}{ll}- & \text { r }\end{array}$ & & $4.3^{\mathrm{HE}}$ & $3.5^{\mathrm{H}}$ & $6.3^{\mathrm{EC}}$ \\
\hline $\mathrm{Cr}$ & $-2.7^{\mathrm{U}}$ & $-3.4^{\mathrm{U}}$ & $-2.2^{\mathrm{U}}$ & $-2.5^{\mathrm{U}}$ & $-3.2^{\mathrm{U}}$ & $-2.8^{\mathrm{U}}$ & $-3.2^{\mathrm{U}}$ & $-3.1^{\mathrm{U}}$ & $-3.9^{\mathrm{U}}$ & - & - & - & $-2.2^{\mathrm{U}}$ & $-2.5^{\mathrm{U}}$ & $-3.2^{\mathrm{U}}$ & $-3.4^{\mathrm{U}}$ & $-3.3^{\mathrm{U}}$ & $-3.1^{\mathrm{U}}$ & - & - & - & $-1.8^{\mathrm{U}}$ & $-3.1^{\mathrm{U}}$ & $-2.4^{\mathrm{U}}$ \\
\hline $\mathrm{Cu}$ & $-3.6^{\mathrm{U}}$ & $-4.5^{\mathrm{U}}$ & $-4.0^{\mathrm{U}}$ & $-4.6^{\mathrm{U}}$ & $-5.3^{\mathrm{U}}$ & $-4.1^{\mathrm{U}}$ & $-4.4^{\mathrm{U}}$ & $-4.7^{\mathrm{U}}$ & $-5.4^{\mathrm{U}}$ & - & - & - & $-4.0^{\mathrm{U}}$ & $-3.8^{\mathrm{U}}$ & $-5.1^{\mathrm{U}}$ & $-4.4^{\mathrm{U}}$ & $-4.2^{\mathrm{U}}$ & $-4.6^{\mathrm{U}}$ & - & - & - & $-2.8^{\mathrm{U}}$ & $-3.7^{\mathrm{U}}$ & $-3.8^{\mathrm{U}}$ \\
\hline $\mathrm{Pb}$ & $-1.8^{\mathrm{U}}$ & $-2.3^{\mathrm{U}}$ & $-2.2^{\mathrm{U}}$ & $-2.1^{\mathrm{U}}$ & $-2.2^{\mathrm{U}}$ & $-1.7^{\mathrm{U}}$ & $-2.4^{\mathrm{U}}$ & $-2.7^{\mathrm{U}}$ & $-2.7^{\mathrm{U}}$ & - & 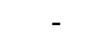 & - & $-0.1^{\mathrm{U}}$ & $-0.2^{\mathrm{U}}$ & $-0.5^{\mathrm{U}}$ & $-0.3^{\mathrm{U}}$ & $-1.0^{\mathrm{U}}$ & $0.3^{\mathrm{UM}}$ & . & - & . & $-0.5^{\mathrm{U}}$ & $-0.4^{\mathrm{U}}$ & $0.3^{\mathrm{UM}}$ \\
\hline $\mathrm{Se}$ & $4.3^{\mathrm{HE}}$ & $4.4^{\mathrm{HE}}$ & $5.0^{\mathrm{HE}}$ & $4.7^{\mathrm{HE}}$ & $4.8^{\mathrm{HE}}$ & $4.1^{\mathrm{HE}}$ & $4.0^{\mathrm{H}}$ & $4.8^{\mathrm{HE}}$ & $4.9^{\mathrm{HE}}$ & . & . & . & $3.9^{\mathrm{H}}$ & $3.9^{\mathrm{H}}$ & $4.2^{\mathrm{HE}}$ & $5.0^{\mathrm{HE}}$ & $3.9^{\mathrm{H}}$ & $4.8^{\mathrm{HE}}$ & . & - & . & $5.0^{\mathrm{HE}}$ & $4.9^{\mathrm{HE}}$ & $5.4^{\mathrm{EC}}$ \\
\hline $\mathrm{Zn}$ & $-2.7^{\mathrm{U}}$ & $-3.1^{\mathrm{U}}$ & $-2.8^{\mathrm{U}}$ & $-2.7^{\mathrm{U}}$ & $-3.0^{\mathrm{U}}$ & $-2.7^{\mathrm{U}}$ & $-3.2^{\mathrm{U}}$ & $-3.3^{\mathrm{U}}$ & $-3.4^{\mathrm{U}}$ & . & - & - & $-2.2^{\mathrm{U}}$ & $-2.0^{\mathrm{U}}$ & $-2.6^{\mathrm{U}}$ & $-2.3^{\mathrm{U}}$ & $-2.5^{\mathrm{U}}$ & $-2.3^{\mathrm{U}}$ & & - & & $-2.2^{\mathrm{U}}$ & $-2.2^{\mathrm{U}}$ & $-1.6^{\mathrm{U}}$ \\
\hline
\end{tabular}




\section{Figure 1}

Study area

Figure 1: (A) Geographic location of State Pahang and Pantai Balok (square box) on the east coast of Peninsular Malaysia; (B) The sampling sites (I-III) in River Balok estuary along with the locations of sand mining ( $(\mathbf{\Lambda})$, wave breaker/parking lot construction and, fishing jetty construction ( ) in the vicinity (Google Map ${ }^{\circ}$ 2013). Photographic evidences show the physical infrastructural developments at Site-I - (C) beach condition in 2009-2010, (D) wave breaker/parking lot construction in 2011 and, (E) fishing jetty construction in 2013.
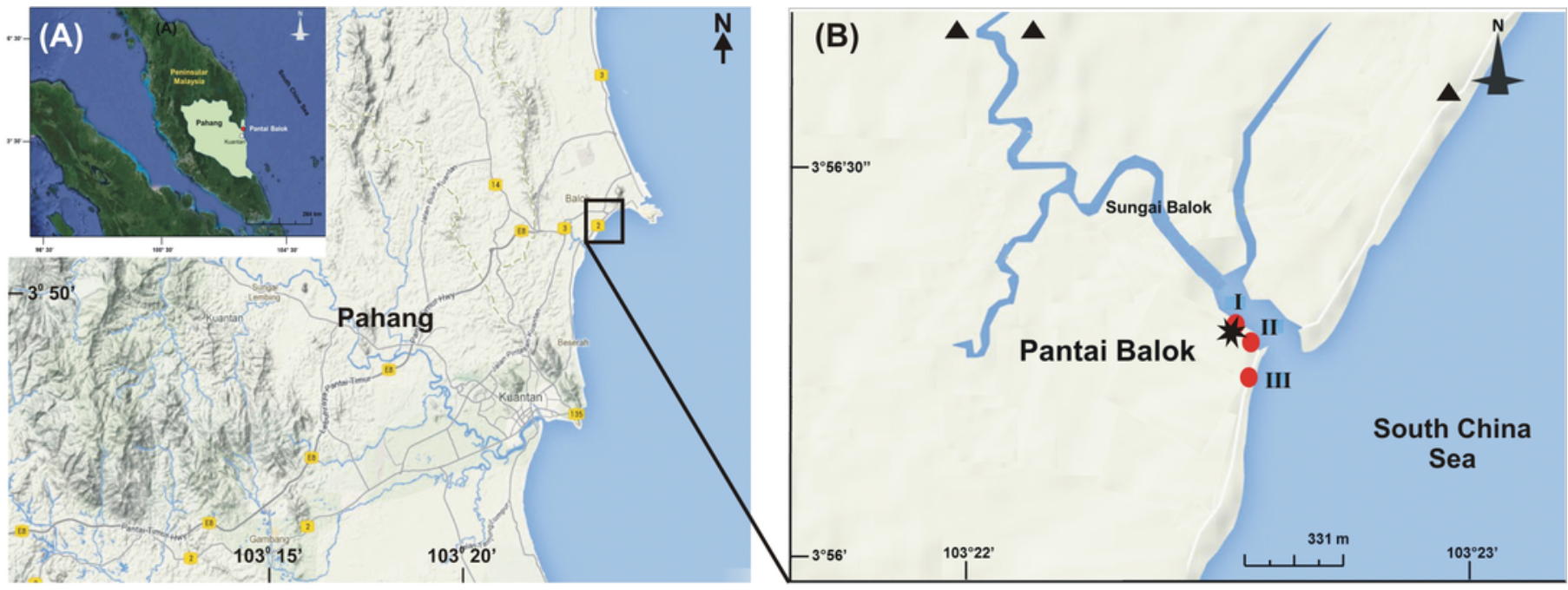

(C)

(D)
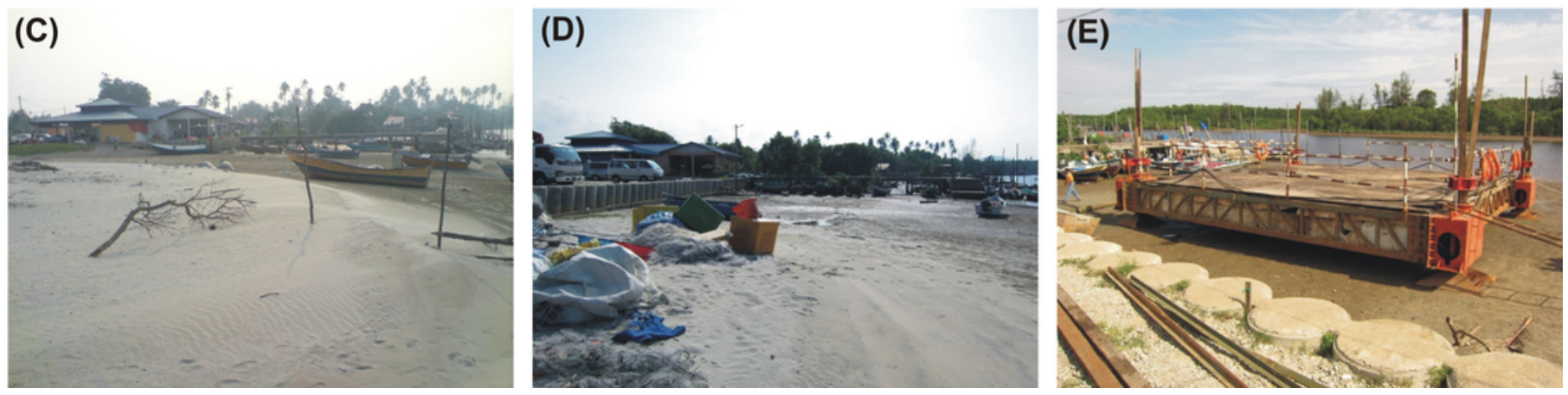
Figure 2

\section{Egg/nest yield of Tachypleus gigas at Pantai Balok}

Figure 2: Egg/nest yield of Tachypleus gigas at Pantai Balok in relation to - (A) season, (B) lunar period (C) sampling sites and, (D) the number of male and female spawning crabs arrived to Balok beach.
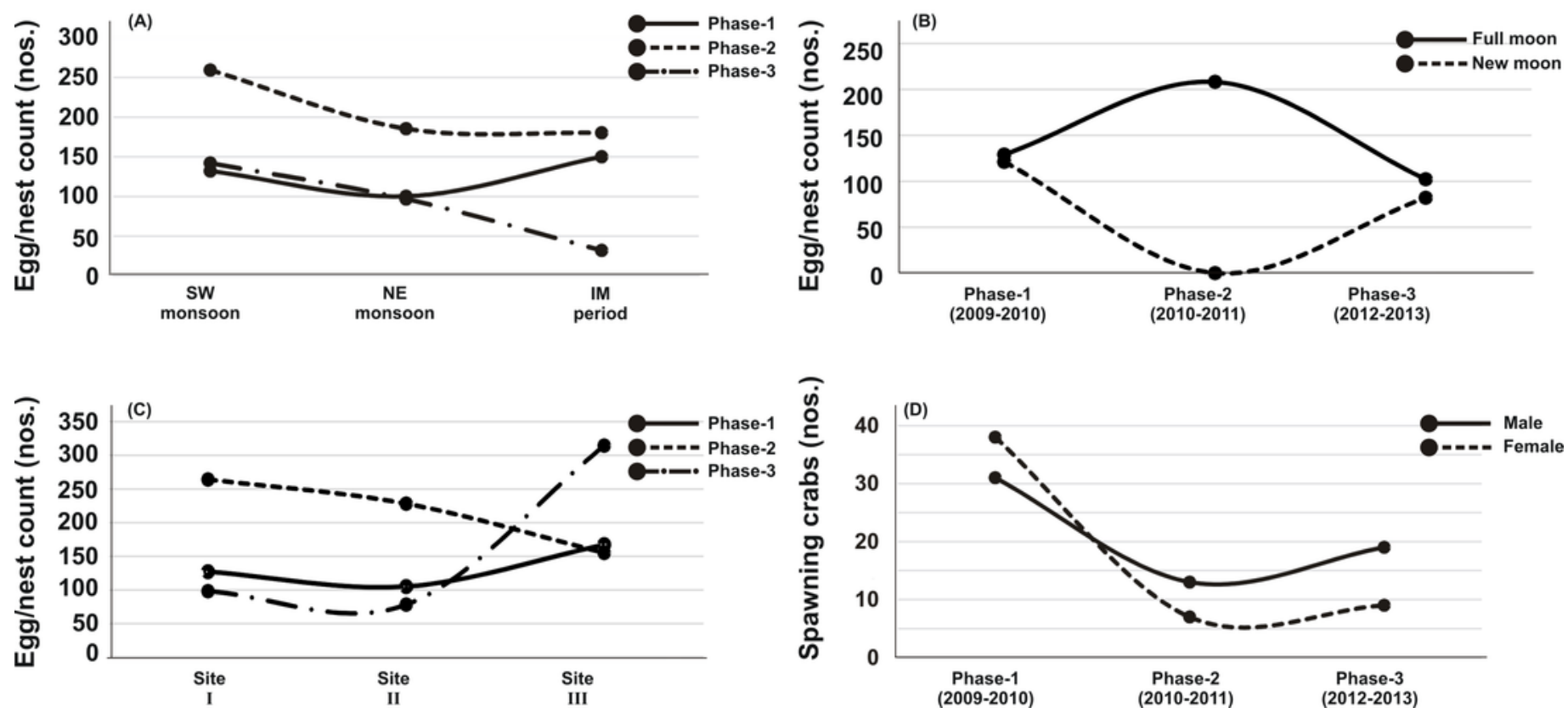


\section{Figure 3}

Principal Component Analysis (PCA) showing thevariance in sedimentological parameters in relation toegg count,season,lunar period andsampling sites of Tachypleus gigas

Figure 3: Principal Component Analysis (PCA) showing the \% variance in sedimentological parameters in relation to - (A) Tachypleus gigas egg count, (B) season, (C) lunar period and, (D) sampling sites. The numbers 1-3 indicate study phases in the present investigation ( 1 = Phase-1: 2009-2010, 2 = Phase-2: 2010-2011 and 3 = Phase-3: 2012-2013). The circle in each panel represents correlation circle and the orientation of the environmental (sediment) lines approximate their correlation to the ordination axes. Abbreviated environmental parameters: Temp $=$ Temperature, Sort $=$ Sorting, Skew $=$ Skewness, Kurt $=$ Kurtosis, Grav $=$ Gravel, $S \& C=$ Silt and clay, $M D=$ Moisture depth and TOC $=$ Total organic carbon .
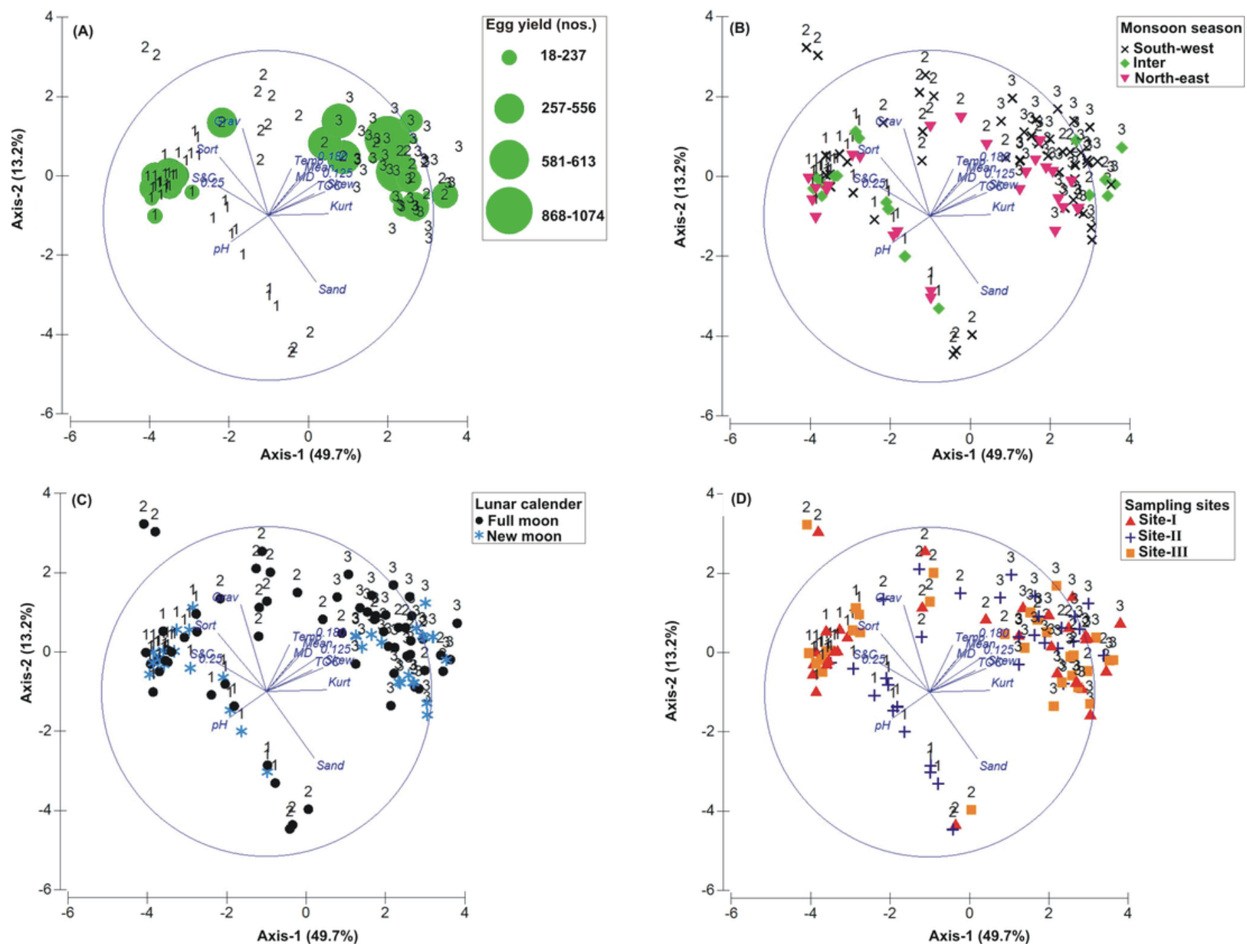


\section{Figure 4}

Principal Component Analysis (PCA) showing thevariance in water quality parameters in relation toegg count,season, lunar period andsampling sites of Tachypleus gigas

Figure 4: Principal Component Analysis (PCA) showing the \% variance in water quality parameters in relation to - (A) Tachypleus gigas egg count, (B) season, (C) lunar period and, (D) sampling sites. The numbers 1-3 indicate study phases in the present investigation ( 1 = Phase-1: 2009-2010, 2 = Phase-2: 2010-2011 and 3 = Phase-3: 2012-2013). The circle in each panel represents correlation circle and the orientation of the environmental (water) lines approximate their correlation to the ordination axes. Abbreviated environmental parameters: Temp = Temperature, Sal = Salinity, DO = Dissolved oxygen, Chl-a $=$ Chlorophyll-a, $\mathrm{NO}_{2}{ }^{-}=$Nitrite, $\mathrm{NO}_{3}{ }^{-}=$Nitrate, $\mathrm{PO}_{4}{ }^{3-}=$ Phosphate, $\mathrm{S}^{2-}=$ Sulphide.
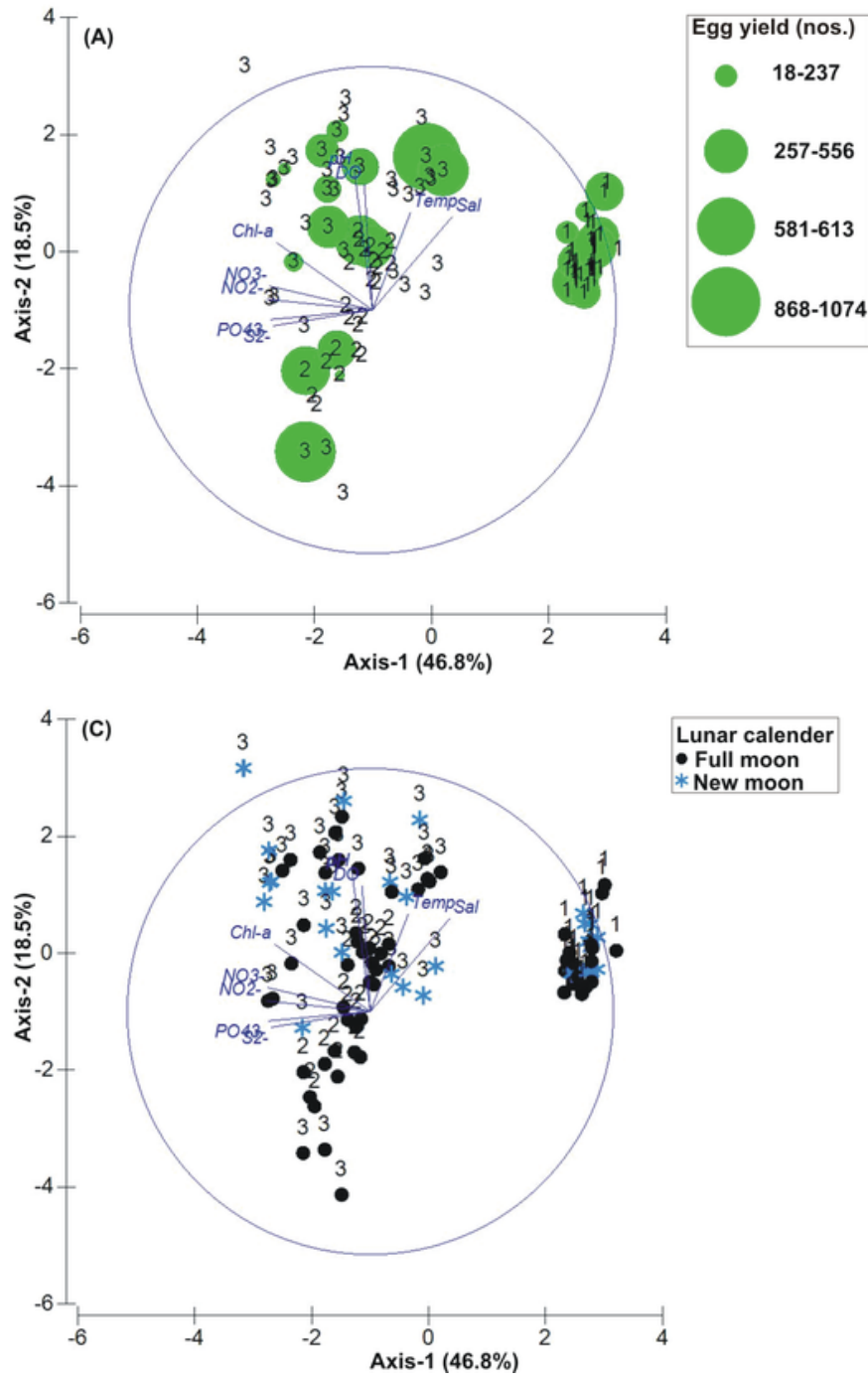
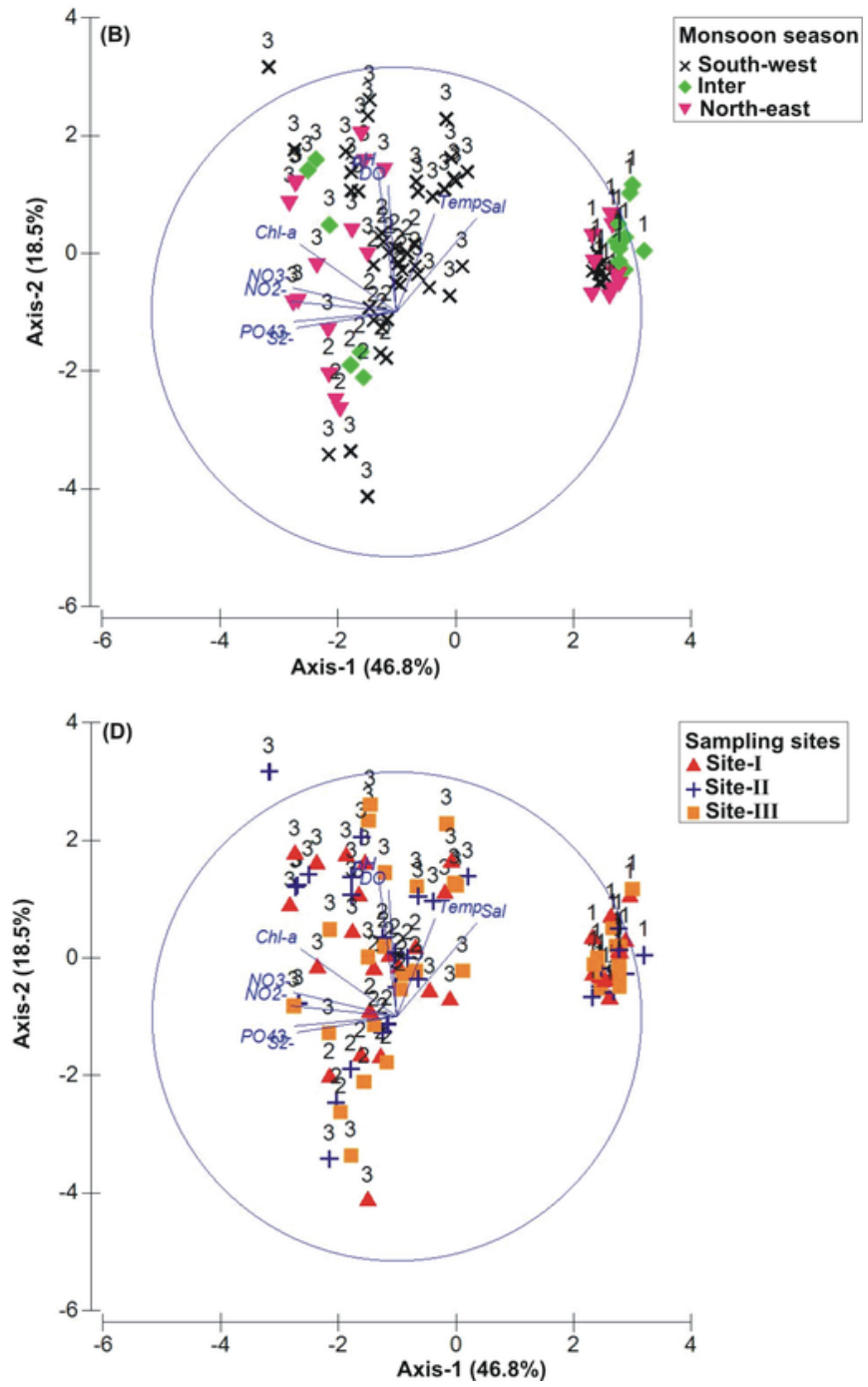


\section{Figure 5}

Principal Component Analysis (PCA) showing thevariance in heavy metals in relation to egg count,season,lunar period and sampling sites of Tachypleus gigas

Figure 5: Principal Component Analysis (PCA) showing the \% variance in heavy metals in relation to - (A) Tachypleus gigas egg count, (B) season, (C) lunar period and, (D) sampling sites. The numbers 2-3 indicate study phases in the present investigation ( 2 = Phase-2: 2010-2011 and 3 = Phase-3: 2012-2013). The circle in each panel represents correlation circle and the orientation of the environmental (heavy metals) lines approximate their correlation to the ordination axes. Abbreviated environmental parameters: $\mathrm{Cd}=$ Cadmium, $\mathrm{Cr}=$ Chromium, $\mathrm{Cu}=$ Copper, $\mathrm{Pb}=$ Lead, $\mathrm{Se}=$ Selenium, $\mathrm{Zn}=$ Zinc.
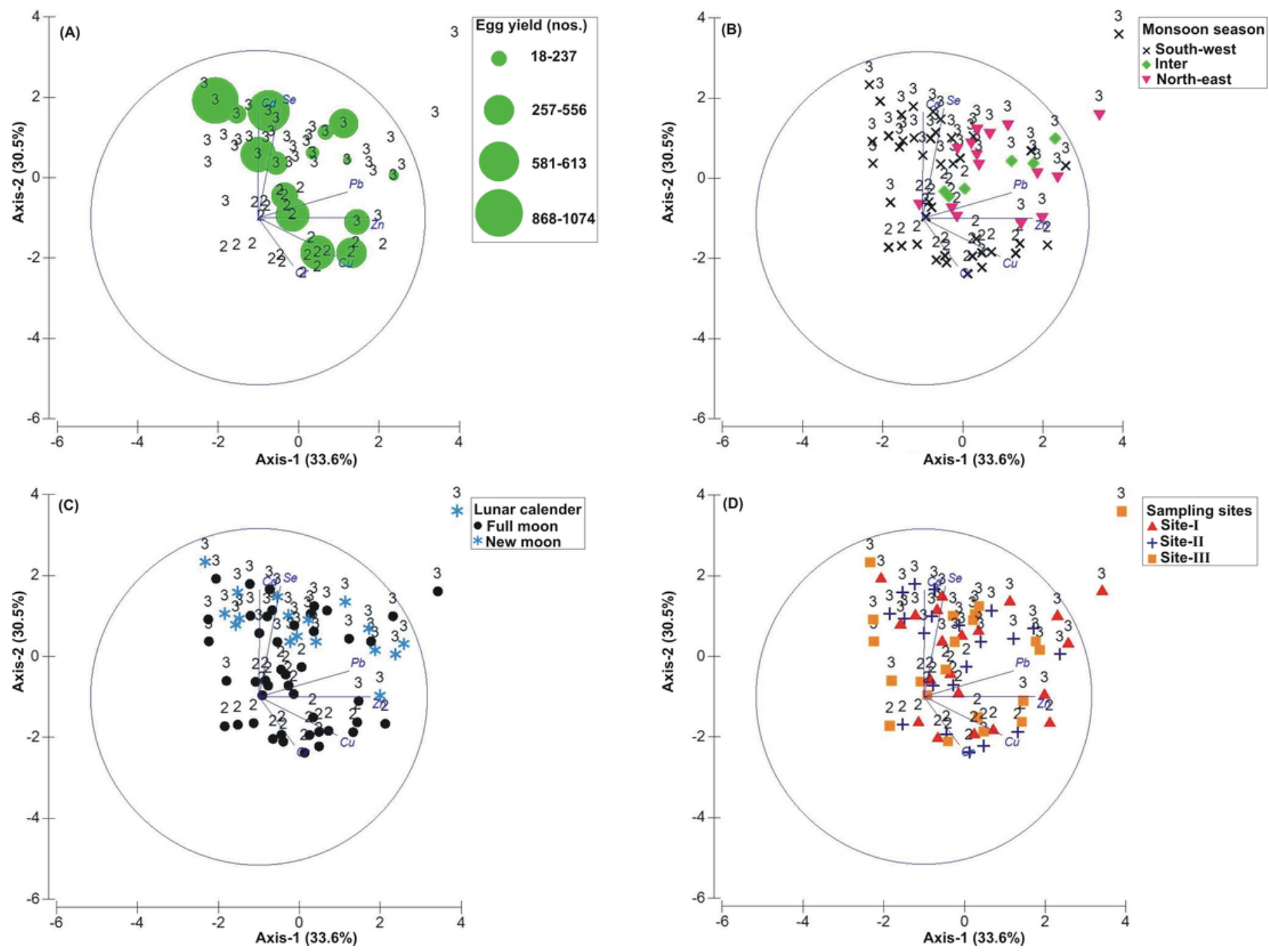


\section{Figure 6}

$\mathrm{S}$ chematic diagram showing the nest shifting behaviour of Tachypleus gigas at Pantai Balo $\mathrm{k}$

Figure 6: $\mathrm{S}$ chematic diagram showing the nest shifting behaviour of Tachypleus gigas in-between the three sampling sites (I-III) at Pantai Balo k (Google Map @ 2013). The impact of environmental processes (indicated in boxes) in relation to monsoon (SW/IM/NE) seasons are found to be important for spawning site(s) selection by the adult crabs.

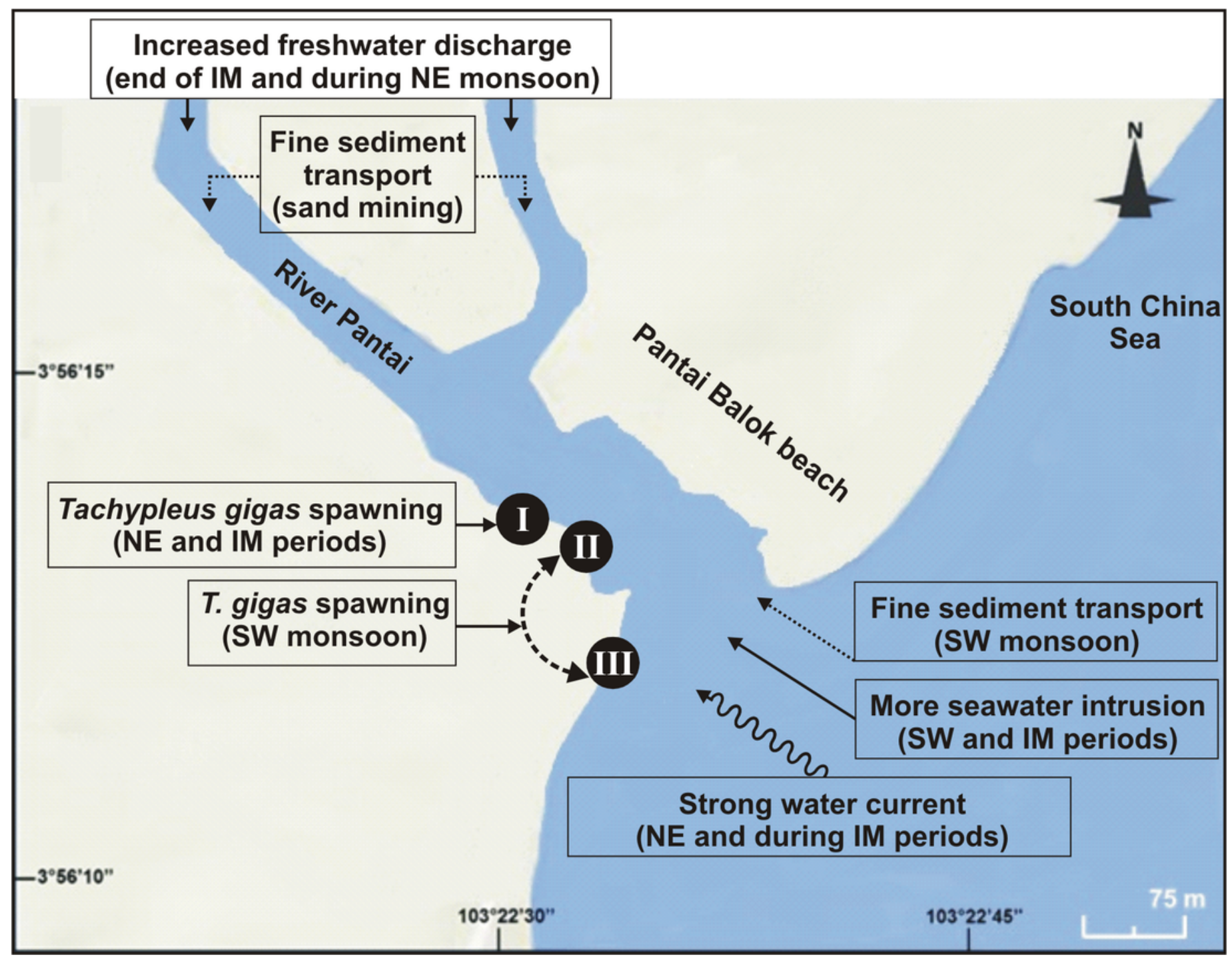

